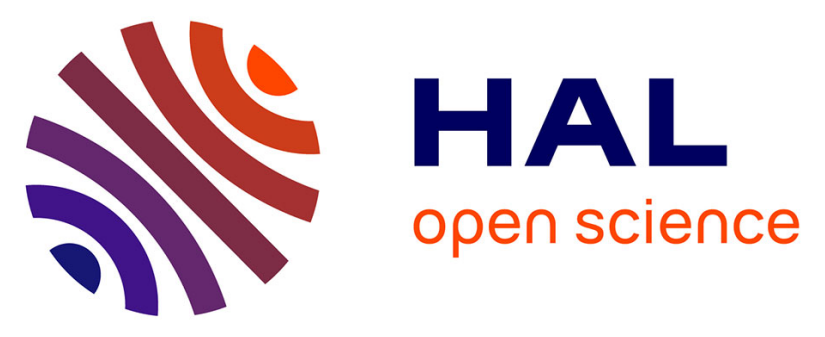

\title{
The Léon Domain (French Massif Armoricain): a westward extension of the Mid-German Crystalline Rise? Structural and geochronological insights
}

Michel Faure, Claire Sommers, Jérémie Melleton, Alain Cocherie, Olivier Lautout

\section{To cite this version:}

Michel Faure, Claire Sommers, Jérémie Melleton, Alain Cocherie, Olivier Lautout. The Léon Domain (French Massif Armoricain): a westward extension of the Mid-German Crystalline Rise? Structural and geochronological insights. International Journal of Earth Sciences, 2010, 99 (1), pp.65-81. 10.1007/s00531-008-0360-x . insu-00352053

\section{HAL Id: insu-00352053 \\ https://hal-insu.archives-ouvertes.fr/insu-00352053}

Submitted on 12 Jan 2009

HAL is a multi-disciplinary open access archive for the deposit and dissemination of scientific research documents, whether they are published or not. The documents may come from teaching and research institutions in France or abroad, or from public or private research centers.
L'archive ouverte pluridisciplinaire HAL, est destinée au dépôt et à la diffusion de documents scientifiques de niveau recherche, publiés ou non, émanant des établissements d'enseignement et de recherche français ou étrangers, des laboratoires publics ou privés. 


\title{
The Léon Domain (French Massif Armoricain): a westward extension of the Mid-German Crystalline Rise? Structural and geochronological insights
}

\author{
Michel Faure $^{1}$, Claire Sommers ${ }^{1}$, Jérémie Melleton ${ }^{1,2}$, Alain Cocherie $^{2}$ and Olivier Lautout ${ }^{1}$ \\ (1) ISTO Campus Géosciences, Orléans University, 1A Rue de la Férollerie, 45071 Orléans \\ Cedex 2, France \\ (2) BRGM, Av. Claude-Guillemin, 45060 Orléans Cedex 2, France
}

\begin{abstract}
The Léon Domain in the NW part of the French Massif Armoricain is a stack of synmetamorphic nappes displaced from south to north in ductile conditions. From bottom to top, an orthogneissic basement is overthrusted successively by (1) a Lower Nappe of gneiss including mafic eclogites, (2) an Intermediate Nappe of biotite-garnet-staurolite micaschists with mafic blocks, and (3) an upper nappe made up of Neoproterozoic phyllites covered by unmetamorphosed Paleozoic sedimentary series. This microstructural study documents a polyphase evolution with firstly a top-to-the-N shearing, secondly followed by upright folding of the stack of nappes coeval with migmatization, and lastly, a dextral wrenching along the North Armorican Shear Zone associated with emplacement of synkinematic plutons. New U$\mathrm{Th} / \mathrm{Pb}$ chemical dating of monazites from biotite-garnet-staurolite micaschists, migmatites, and granitoids argue for 340-335 Ma, 335-327 Ma, and about $320 \mathrm{Ma}$ ages for synthrusting metamorphism, anatexis, and wrenching, respectively. A metagabbro from Le Conquet yields a zircon LA-ICP-MS age of $478 \pm 4 \mathrm{Ma}$, which corresponds to magma emplacement time. The Léon Domain is interpreted as a microcontinent separated from Armorica by the Le Conquet-Penzé suture to the south and east, and from Laurussia by the Rheic suture to the north. A possible correlation with the Mid-German Crystalline Rise of Central Europe is discussed.
\end{abstract}

Keywords Variscan belt - Microcontinent collision - Crustal melting - U- $\mathrm{Th} / \mathrm{Pb}$ chemical dating - Paleozoic - Massif Armoricain - Mid-German Crystalline Rise

\section{Introduction}

The Paleozoic Variscan Orogeny was responsible for the formation of the basement of MedioEuropa from Iberia to central Europe. It is widely accepted that the Variscan Belt resulted from a complex interplay between the three large continents Laurentia, Baltica, and Gondwana, and several intervening microcontinents such as Avalonia or Armorica (e.g., Matte 1986, 2001; Franke 2000; Paris and Robardet 1990; Pin 1990, Tait et al. 1997; Robardet 2003; Von Raumer et al. 2002). Although authors acknowledge that the Variscan Belt is a collisional orogen, the location and age of the sutures, the timing of the tectonicmetamorphic events, and the resulting structures remain controversial.

In France, a Silurian-Devonian east-west trending, Eo-Variscan suture, corresponding to the closure of the Medio-European Ocean is recognized in the southern part of the Massif Armoricain (Fig. 1; Matte 1986; Matte and Hirn 1988; Faure et al. 2005). This suture extends eastward, north of the Massif Central, below the southern part of the Mesozoic Paris basin. Another suture, called the Rheic suture, is inferred to exist north of the Massif Armoricain, in the British Channel, along the Bray fault and probably between the Vosges and the Ardennes. The domain located between these two main sutures corresponds to the Armorica 
microcontinent (Matte 2001). Most of the Massif Armoricain belongs to Armorica. However, its northwestern part, called Léon Domain, consists of metamorphic rocks different from the nearby Paleozoic rocks of Central Armorica. The boundary between the Léon Domain and Armorica, which forms the main part of the Massif Armoricain, is tectonic, and marked by mafic magmatic rocks. The geodynamic evolution of the Léon Domain is still in debate. Several interpretations have been proposed (e.g., Cabanis et al. 1979; Balé and Brun 1986; Rolet et al. 1986, 1994; Le Corre et al. 1989, 1991; Faure et al. 2005, cf. below). This paper provides new structural and geochronological evidence suggesting that the Léon Domain can be considered as a distinct microcontinent drifted from Armorica and rewelded to it by northdirected thrusting.

\section{Geological setting: the Léon Domain in the Massif Armoricain}

The Massif Armoricain is one of the largest areas where the Variscan belt can be analyzed. This composite massif can be subdivided into several paleogeographic or tectonic domains (e.g., Cogné 1974; Le Corre et al. 1991; Rolet et al. 1994). Its structure is dominated by E-W trending dextral shear zones (Fig. 1). Both the North Armorican shear zone (NASZ) and the South Armorican shear zone (SASZ) split eastward into several branches. These hundred kilometer-long ductile faults are Middle to Late Carboniferous structures, active around 325$300 \mathrm{Ma}$, and developed within an already assembled continent. Thus, when dealing with early Variscan tectonics (i.e. before Visean), three domains can be recognized there, namely (1) the South Armorican Domain, (2) the North-Central Armorican Domain, and (3) the Léon Domain (Fig. 1).

The South Armorican Domain is bounded to the North by the Nort-sur-Erdre fault and the SASZ. The former corresponds to the Eo-Variscan suture. The South Armorican Domain is lithologically and structurally similar to the Massif Central, both are formed by pre-Visean metamorphic rocks, migmatites, granitoids, and Paleozoic sedimentary rocks. It is well acknowledged that the South Armorican Domain is a stack of nappes overthrust to the south (e.g., Marchand 1981; Ballèvre et al. 1994; Faure et al. 2005 and enclosed references). By analogy with the Massif Central (Ledru et al. 1989), the following litho-tectonic units are recognized from bottom to top. The Para-Autochthonous Unit, composed of micaschist, grauwacke, and quartzite, is recognized in the southern part of the Massif. The Lower Gneiss Unit (LGU) consists of orthogneiss, paragneiss, and micaschist. The Upper Gneiss Unit (UGU) formed by orthogneiss, paragneiss, and mafic rocks experienced a high-pressure metamorphism followed by crustal melting. In contrast to the Massif Central where the UGU represents the uppermost unit, in the Massif Armoricain, the UGU was successively overthrust by (1) an ophiolitic nappe and (2) a basement nappe. The ophiolitic nappe consists of highly deformed metagabbro, amphibolite, serpentinized ultramafics, and metasedimentary rocks. The basement nappe, also called the Mauges Nappe, is made up of Neoproterozoic (i.e. Brioverian) metamorphic rocks formed during the Cadomian orogeny, unconformably overlain by Cambrian-Ordovician terrigeneous sedimentary rocks. The stack of nappes developed during the collision between the South and North-Central Armorican domains representing the North Gondwana margin and the Armorica microcontinent, respectively.

The North-Central Armorican Domain, the widest one, is formed by unmetamorphosed and weakly deformed Paleozoic sedimentary series underlain by a Neoproterozoic basement formed during the Cadomian orogeny. The structure of the North-Central Armorican Domain is rather simple, $\mathrm{E}-\mathrm{W}$ trending upright folds associated with a vertical axial planar cleavage developed during the dextral shearing along the NASZ and the SASZ. Several Middle to Late 
Carboniferous granitic plutons intrude the sedimentary succession; some of them are synkinematic bodies coeval with the dextral shearing.

The Léon Domain (Fig. 1) is the smallest one of the Massif Armoricain. In spite of numerous Carboniferous plutons that partly hide the structural relationships between the units, an antiformal stack of nappes is presently recognized (Le Corre et al. 1989; Rolet et al. 1994; Faure et al. 2005; Fig. 2). From bottom to top, the structure of the Léon Domain consists of the following succession. The Para-Autochthonous Unit corresponds to paragneiss intruded by augen orthogneiss (Tréglonou and Plounevez-Lochrist), the emplacement of which is dated at $385 \pm 8 \mathrm{Ma}$ by $\mathrm{Rb}-\mathrm{Sr}$ method on whole rock, and $400 \pm 40 \mathrm{Ma}$ by U-Pb method on zircon fractions (Cabanis et al. 1979). Both the augen gneiss and country rocks experienced a pervasive migmatization, the age of which is provided for the first time in this paper. The Lower Nappe is formed by a biotite-garnet-sillimanite gneiss series that encloses eclogitic rocks mostly retrogressed into amphibolite and derived from tholeiitic gabbro or basalt. Pyroxenites and serpentinites crop out locally. Pressure and temperature $(\mathrm{P}-\mathrm{T})$ conditions for the eclogitic metamorphism are estimated around $14-15 \mathrm{kbar}$ and $650-700^{\circ} \mathrm{C}$, respectively (Cabanis and Godard 1987). U/Pb dates from zircons provide an age of $439 \pm 12 \mathrm{Ma}$, which is considered as that of the high-pressure metamorphism (Paquette et al. 1987). The Intermediate Nappe or Le Conquet-Penzé Nappe consists of ortho- and para-derived amphibolite, metagabbro, biotite-garnet-staurolite micaschist, and metachert. The micaschists commonly include biotite-garnet-staurolite metapelites, and locally garnet porphyroblasts reach $1 \mathrm{~cm}$ in size. The close association of blue kyanite with quartz and muscovite suggests that it crystallized during a postmetamorphic hydrothermal event rather than during the regional metamorphism (Chauris and Hallégouet 1989). The Upper Nappe consists of Late Proterozoic micaschists intruded by Ordovician granodiorites, presently deformed into orthogneiss, called the Brest orthogneiss. The Brest orthogneiss yields zircon $\mathrm{U}-\mathrm{Pb}$ and whole rock $\mathrm{Rb}-\mathrm{Sr}$ ages of $460 \pm 70$ and $466 \pm 25 \mathrm{Ma}$, respectively. In spite of their poor quality, these dates argue for an Early Ordovician age for the pluton emplacement (Deutsch and Chauris 1965; Cabanis et al. 1979). Weakly deformed Ordovician white quartzite and pelite form the Paleozoic cover of the Proterozoic basement of the Central-North Armorican Domain that crops out immediately south of the Brest orthogneiss. Locally, NE of Brest and east of Penzé, a decollement separates the Paleozoic sedimentary cover from its Proterozoic basement (Fig. 2). To the south, the stack of nappes of the Léon Domain is cut by the dextral strike-slip Elorn fault, which is a branch of the North Armorican Shear Zone. To the east, around the Penzé River, the general trend of the bedding of the sedimentary rocks, the metamorphic foliation, and the tectonic boundaries turn N-S. The following section provides microtectonic analyses of the Le Conquet and Penzé areas that document the polyphase deformation and north-directed shearing. Several granitic plutons intrude the nappe pile (Fig. 2). The Aber-Ildut, Kernilis, Brignogan, and Plouescat plutons are Late Carboniferous meta or peraluminous granites or monzogranites (Le Corre et al. 1989, 1991). The St-RenanKersaint pluton is an E-W elongated body whose sigmoidal shape, internal structure, and S-C structures indicate an emplacement contemporaneous with the dextral shearing of the NASZ (Goré and Le Corre 1987 Le Corre et al. 1989; Schultz et al. 2007).

The tectonic evolution of the Léon Domain can be summarized as a sequence of four main events:

1. The HP metamorphism, dated at $439+12 /-13 \mathrm{Ma}$ (Paquette et al. 1987), developed in oceanic mafic rocks. Because of the retrogression under amphibolite facies conditions, the early syn-HP deformation of the eclogites is poorly understood. 
2. The main event observed in all units is the top-to-the-NW synmetamorphic shearing developed under amphibolite facies conditions. In the Para-Autochthonous Unit, the Penzé-Le Conquet Intermediate Nappe, and the Paleozoic series of the Upper Nappe, this synmetamorphic deformation is the earliest one recorded there, and responsible for the stacking of nappes (Balé and Brun 1986, Le Corre et al. 1989; Rolet et al. 1994; Faure et al. 2005).

3. As it is the case in many orogens, crustal thickening was responsible for anatexis of the most pelitic and hydrated rocks. In the Léon Domain, crustal melting developed mainly in the Lower Nappe in relation to the formation of the antiformal structure that refolded the nappe stack.

4. Lastly, several generations of granitic plutons cut across the earlier structures. The StRenan-Kersaint pluton, which is the largest one in the Léon Domain, is a synkinematic body emplaced along the dextral North Armorican Shear Zone (Goré and Le Corre 1987).

\section{Structural analyses of the Le Conquet and Penzé areas Le Conquet area}

Because of excellent exposure conditions and its mean N-S orientation, the coast line between the Pointe St-Mathieu and Kerhornou is the most convenient place to analyze the structure of the southern boundary of the Léon Domain (Fig. 3; Chauris and Hallégouet 1989). The tectonic units and the geometry described in the previous section are well exposed. From south to north, they are (1) the Brest orthogneiss and its Neoproterozoic Elorn micaschists host rocks, (2) the Conquet micaschists with mafic rocks, and (3) the Kerhornou migmatitic gneiss with numerous pods and dykes of anatectic granitoids. To the north, near Kerhornou, migmatites are well developed and the protoliths of the migmatite cannot be identified any more. The North Armorican shear zone separates the Le Conquet metamorphic rocks from the St-Renan-Kersaint pluton. Along the NASZ, the granite is pervasively foliated with a subvertical attitude and contains a subhorizontal mineral lineation. S-C shear criteria confirm the dextral sense of shear along the NASZ.

The Brest orthogneiss exhibits a steeply southward dipping NE-SW trending foliation in which two sets of stretching lineation can be distinguished (Fig. 3). The dominant one is well observed close to the northern boundary of the orthogneiss with Le Conquet metamorphic rocks. The vertical foliation ( $X Y$ plane) contains a subhorizontal or weakly plunging to the southwest stretching lineation ( $X$ axis) represented by biotite streaks, quartz rods, elongated or boudinaged feldspar augens. In agreement with Balé and Brun (1986), kinematic indicators such as sigma-type porphyroclast systems, meter-scale shear zones, or shear bands provide a dextral sense of shear. Moreover, an early N155E to N170E steeply plunging lineation is also observed on the orthogneiss foliation. In sections perpendicular to the foliation and parallel to the N-S trending lineation, sigma-type porphyroclast systems and shear bands indicate top-tothe-N ductile shearing. This lineation is less developed than the NW-SE one as strike-slip shearing partly erased it. The boundary between the Brest orthogneiss and the Le Conquet micaschists is a strike-slip shear zone. However, an older, north-directed thrust contact, coeval with the $\mathrm{N}-\mathrm{S}$ stretching lineation, can be documented on the basis of the microtectonic analysis of Le Conquet micaschists.

North of the wrench fault, metagabbro, diabase, and amphibolite boudins form a remarkable lithology within the Le Conquet micaschists series. Quartzite and conglomeratic lenses also develop in the metapelites (Fig. 4). Because of the poor outcrop conditions inland, the 
geometry and significance of these lenses remain uncertain. They might be continuous layers, interstratified with the metapelites, or olistoliths. Quartz lenses are also pervasively distributed throughout the Conquet micaschists (Fig. 4). The locally high concentration of veins suggests that they formed along ductile shear zones with abundant fluid circulation. In this unit, a pervasive NNE-SSW lineation is marked by elongated amphiboles in the mafic rocks, stretched clasts in the paragneiss, quartz pressure shadows around garnet in micaschists, or elongated quartz rods. Kinematic indicators such as asymmetric pressure shadows, sigma-type porphyroclasts systems, sigmoidal biotite, rotating inclusions in garnet or asymmetric quartz veins show a top-to-the-N sense of shear (Figs. 4, 5, 6).

The northernmost unit of the Le Conquet area is the Kerhornou biotite-garnet-sillimanite paragneiss. These rocks contain abundant centimeter- to decimeter-sized pockets of quartzfeldspar-biotite leucosomes related to an incipient crustal melting. The transition from highgrade gneiss to sillimanite metatexites and diatexites is progressive. In places, meter- to several meter-sized granitoid dykes with numerous xenoliths of biotite-sillimanite gneiss correspond to anatectic granites (Fig. 4). As a whole, the Kerhornou gneiss, migmatites and anatectic granites suite is the lowest unit observed in the Le Conquet area. It belongs to the Lower Nappe of the Léon Domain (Fig. 2) in which a high-temperature metamorphic and plutonic event overprinted the HP eclogitic metamorphism. However, in the Le Conquet section, HP rocks have not yet been identified. In this unit, the mineral lineation is less developed than in the ones described above, but NNE-SSW trending biotite streaks or quartz rods are also observed where migmatization is absent. In the Kerhornou gneiss, kinematic indicators are rare and the synmetamorphic sense of shear is difficult to assess. The stretching lineation of the Kerhornou gneiss is parallel to that found in the Le Conquet micaschists. This observation suggests that in both units the lineation formed coevally, during north-directed nappe stacking. In gneiss where anatexis is not well developed, the older fabric of the protolith is still preserved. This shows that the above described north-directed ductile deformation is older than crustal melting. Moreover, the foliation is deformed by an E-W trending, heterogeneously developed crenulation cleavage. Millimeter- to centimeter-scale microfolds are overturned to the north. This structure, which is also observed in the migmatite, is likely related to the upright folding of the stack of nappes.

\section{Penzé area}

The eastern boundary of the Léon Domain is well exposed along the Penzé River (Fig. 7). There, the regional structural trend is north-northeasterly, but southeast of Penzé, the foliation turns into a NE-SW direction. From bottom to top, the following units are recognized. The Penzé micaschists consist of biotite-muscovite-oligoclase metapelites. Locally, staurolite and garnet are also present, but in contrast to the Le Conquet area, centimeter-sized porphyroblasts are rare. Mafic rocks such as metagabbro, amphibolite, mafic schists form elongated lenses scattered in the metapelites. Because of the intense ductile shearing and recrystallization, it is rather difficult to state if these rocks are olistoliths or tectonic boudins. The Penzé micaschists are overlain by sericite phyllite, metagrauwacke, and metasandstone. In the sericitic quartz phyllite, detrital plagioclase grains are common, while being quite rare in the underlying micaschists. To the east, this series in covered by unmetamorphosed conglomerate, quartzite, sandstone, and mudstone of Paleozoic age. Furthermore, Ordovician granites, changed into orthogneiss, intrude the sericitic phyllite (Fig. 7). Therefore, a Neoproterozoic age (Brioverian) is likely for the micaschists. At the scale of the Léon Domain, the Penzé micaschists, Neoproterozoic phyllites, and orthogneiss are correlated with the Le Conquet micaschists, Elorn micaschists, and Brest orthogneiss, respectively (Fig. 2). 
Although never observed in the field, but in agreement with previous works (Rolet et al. 1994; Chauris et al. 1998), a tectonic contact between the Penzé micaschists and the overlying Neoproterozoic Cadomian micaschists is assumed (Figs. 7, 8). West of Morlaix, the sandstone and conglomerate that form the base of the Devonian sedimentary series show a welldeveloped bedding-parallel cleavage and a stretching lineation.

Except for the Paleozoic sedimentary rocks, the metamorphic rocks exhibit a N-S- to NESW-trending and E- or SE-dipping pervasive foliation and an E-W- or NW-SE-trending stretching lineation (Fig. 5). Shear criteria, such as sigmoidal micas in micaschists, sigmatype porphyroclast systems in orthogneiss, chlorite pressure shadows around hornblende clasts in metagabbro, indicate a top-to-the-west (or NW) sense of shear (Fig. 6). The foliation is also deformed by west-verging or upright NE-SW-trending folds often associated with a crenulation cleavage.

In addition to the Penzé and Le Conquet key areas, microstructural observations have been also carried out in several other places. For instance, the Tréglonou and Plounévez-Lochrist orthogneiss exhibit a NNW-SSW stretching lineation and top-to-the-NNW sense of shear (Fig. 5), supporting the interpretation that the nappes of the Léon Domain moved from south (or southeast) to north (or northwest).

\section{Geochronological constraints Previous radiometric dating}

As radiometric constraints supporting the abovepresented evolution are rare and rather ancient (Deutsch and Chauris 1965; Leutwein et al. 1969; Cabanis et al. 1979), a geochronological investigation has been carried out. The Léon Domain has long been considered as a piece of the Proterozoic basement of northern Brittany and Normandy (e.g., Cogné 1974 and enclosed references). However, radiometric dating has clearly demonstrated that the main structure of the Léon Domain was acquired during the Paleozoic Variscan orogeny. The augen orthogneiss of Tréglonou and Plounévez-Lochrist, which form the lowermost unit, yield a whole rock (WR) $\mathrm{Rb}-\mathrm{Sr}$ age of $385 \pm 8 \mathrm{Ma}$ and a zircon $\mathrm{U} / \mathrm{Pb}$ age of $400 \pm 40 \mathrm{Ma}$ (Fig. 9; Cabanis et al. 1979). These Early Devonian ages are considered as the ages of the emplacement of the granitic protolith. The Brest orthogneiss yields a zircon $\mathrm{U} / \mathrm{Pb}$ age of $460 \pm 70 \mathrm{Ma}$ (Deutsch and Chauris 1965). The zircon $\mathrm{U} / \mathrm{Pb}$ measurements from an eclogite of the Lower Nappe gave a Concordia lower intercept at $439+12 /-13 \mathrm{Ma}$ that is interpreted as the age of the high-pressure metamorphism (Paquette et al. 1987).

The St-Renan-Kersaint pluton has been dated by the $\mathrm{Rb} / \mathrm{Sr}$ method on whole rock at $320 \mathrm{Ma}$ (Deutsch and Chauris 1965; Leutwein et al. 1969), and around 350-340 Ma by U/Pb method on zircon (Deutsch and Chauris 1965; Leutwein et al. 1969). A biotite concentrate of the same rock, yielded a K-Ar age of $340 \pm 15 \mathrm{Ma}$ (Leutwein et al. 1969). Thus, the ages of the metamorphic events are almost not documented. The age of the anatexis is sometimes assumed as that of the St-Renan pluton, since the migmatites are considered to have resulted from the thermal metamorphism related to pluton intrusion. However, for some authors, anatexis should have followed closely the high-pressure metamorphism and thus has been assumed as Silurian or Devonian (Le Corre et al. 1989; Ballèvre et al. 1994). 


\section{Monazite $\mathrm{U}-\mathrm{Th} / \mathrm{Pb}$ chemical ages}

Over the past 15 years, chemical geochronology on monazite has become possible (e.g., Suzuki and Adachi 1991; Montel et al. 1996; Cocherie et al. 1998, 2005). Because of its high $\mathrm{U}-\mathrm{Th}$ contents and negligible common $\mathrm{Pb}$ content (Parrish, 1990), monazite constitutes one of the phases frequently used in geochronology. Its use as radiochronometer is enhanced by the restricted lead diffusion in the monazite lattice (Montel et al. 1996; 2000; Cocherie et al. 1998) and by its temperature stability up to more than $900^{\circ} \mathrm{C}$ (Braun et al. 1998). To understand accurately the thermal and tectonic history experienced by a rock, geochronological data must be acquired in situ, that is to say, grains are directly analyzed with respect to their textural environment in thin section (e.g., Pyle et al. 2001; Williams and Jercinovic 2002; Be Mezème et al. 2005). Scanning electron microprobe (SEM) in backscattered electron (bse) mode is one of the best means to distinguish constituent mineral species of the thin section. Detailed analytical procedures were given by Cocherie et al. (1998). The theoretical procedures to reduce the data and to calculate the average age from individual spot analyses are given by Cocherie and Albarède (2001), Cocherie et al. (2005), and Cocherie and Legendre (2007). The analyzed grains from thin section were prepared and analyzed by a Cameca SX 50 EPMA co-operated by BRGM-CNRS-Orléans University. The $2 \sigma$ errors given on individual ages depend on $\mathrm{U}$, Th, and $\mathrm{Pb}$ contents and are calculated by propagating the uncertainties of these elements (with 95\% confidence level). However, because the mean age of an homogeneous age population can be calculated directly from the isochron plot $\mathrm{Th} / \mathrm{Pb}$ versus $\mathrm{U} / \mathrm{Pb}$, only the uncertainty on these two parameters $(\mathrm{Th} / \mathrm{Pb}$ and $\mathrm{U} / \mathrm{Pb}$ ) are required to calculate the uncertainty of the mean age. Age calculations were done using the Isoplot/Ex (3.1) program of Ludwig (2004) and a Microsoft Excel add-in program for determining $\mathrm{U}-\mathrm{Th}-\mathrm{Pb}$ ages from EPMA measurements (Pommier et al., 2002).

In the study area, one sample of biotite-garnet-staurolite micaschist (LE 5), three samples of migmatite (LE 21, LE 23, LE 27), one of anatectic granite (LE 17), and one of the St-Renan granite (LE 20) have been analyzed.

A biotite-garnet-staurolite micaschist (LE 05) has been sampled in Le Conquet (N $\left.48^{\circ} 21^{\prime} 32^{\prime \prime} / \mathrm{W} 4^{\circ} 47^{\prime} 00^{\prime \prime}\right)$. Five, non-zoned grains with sizes ranging from 50 to $100 \mu \mathrm{m}$ have been analyzed. The intercept ages are similar within errors, since the $\mathrm{U}-\mathrm{Pb}$ age (intercept with $\mathrm{U}-\mathrm{Pb}$ axis) and $\mathrm{Th}-\mathrm{Pb}$ age (intercept with $\mathrm{Th}-\mathrm{Pb}$ axis) are $359+31-36$ and $322+28-24 \mathrm{Ma}$, respectively. The MSWD (1.1 for 93 analyses) is compatible with a single age population. Monazite grains yield a mean age of $338 \pm 5 \mathrm{Ma}$ (at $2 \sigma$ confidence level; Fig. 10).

Sample LE 21 is a metatexite that crops out north of the Kerhornou gneiss (Fig. 3; N $\left.48^{\circ} 24^{\prime} 30^{\prime \prime} / \mathrm{W} 4^{\circ} 46^{\prime} 22^{\prime \prime}\right)$. The five analyzed monazite grains are included in biotite; their size ranges from 40 to $150 \mu \mathrm{m}$. The intercept ages are similar within errors, since the $\mathrm{U}-\mathrm{Pb}$ age (intercept with $\mathrm{U}-\mathrm{Pb}$ axis) and the $\mathrm{Th}-\mathrm{Pb}$ age (intercept with $\mathrm{Th}-\mathrm{Pb}$ axis) are at $367+59 /-75$ and 302 $+39 /-31 \mathrm{Ma}$, respectively. In addition, the MSWD of 1.4 indicates that the population of 157 analyses is statistically homogeneous within the analytical errors (Wendt and Carl 1991). As a consequence, it is possible to calculate the mean age at the centroid of the population, where the precision is the best within the error envelope. Thus, the monazite grains yield a mean age of $325 \pm 5 \mathrm{Ma}$ (at $2 \sigma$ confidence level; Fig. 11).

Sample LE 23 is a metatexite from the right bank of Aber Benoît (N 48 33'50"/W 435'). Four monazite grains included in biotite with sizes ranging from 50 to $270 \mu \mathrm{m}$ have been analyzed. The grains are not zoned and the intercept ages are similar within errors, since the 
$\mathrm{U}-\mathrm{Pb}$ age (intercept with $\mathrm{U}-\mathrm{Pb}$ axis) and the $\mathrm{Th}-\mathrm{Pb}$ age (intercept with $\mathrm{Th}-\mathrm{Pb}$ axis) are at $323+50 /-67$ and $343+56 /-42 \mathrm{Ma}$, respectively. On the other hand, an acceptable MSWD of 1.5 has been calculated from 115 analyses. Monazite grains yield a mean age of $334 \pm 6 \mathrm{Ma}$ (at $2 \sigma$ confidence level; Fig. 12).

Sample LE 27 is a metatexite from an old quarry south of Plounévez-Lochrist ( $\mathrm{N}$ $\left.48^{\circ} 36^{\prime} 27^{\prime} 6^{\prime \prime} / \mathrm{W} 4^{\circ} 12^{\prime} 20^{\prime \prime}\right)$. Five nonzoned monazite grains included in biotite or in muscovite with sizes ranging from 60 to $170 \mu \mathrm{m}$ have been analyzed. Because of rather constant $\mathrm{Th} / \mathrm{U}$ ratio, the regression line is poorly defined and is responsible for a large error envelope. Nevertheless, the intercept ages are similar within errors, since the U-Pb age (intercept with $\mathrm{U}-\mathrm{Pb}$ axis) and the $\mathrm{Th}-\mathrm{Pb}$ age (intercept with $\mathrm{Th}-\mathrm{Pb}$ axis) are at $306+127 /-246$ and $347+148 /-80 \mathrm{Ma}$, respectively. The low MSWD parameter (1.2) also indicates that the 106 analyses can be associated to the same event. Monazite grains yield a mean age of $331 \pm 6 \mathrm{Ma}$ (at $2 \sigma$ confidence level; Fig. 13).

The anatectic granite (LE 17) has been sampled south of the LE 21 migmatite (N $\left.48^{\circ} 22^{\prime} 21^{\prime \prime} / \mathrm{W} 4^{\circ} 45^{\prime} 31^{\prime \prime}\right)$. Eight nonzoned grains with sizes ranging from 50 to $100 \mu \mathrm{m}$ have been analyzed. The intercept ages are similar within errors, since the U-Pb age (intercept with $\mathrm{U}-\mathrm{Pb}$ axis) and the $\mathrm{Th}-\mathrm{Pb}$ age (intercept with $\mathrm{Th}-\mathrm{Pb}$ axis) are at $230+135 /-201$ and $368+84 /-58 \mathrm{Ma}$, respectively. The MSWD is also compatible with a single age population (1.2 for 54 analyses). The limited number of analyses and the low $U+T h$ content lead to a higher error on the mean age. Monazite grains yield a mean age of $327 \pm 15 \mathrm{Ma}$ (at $2 \sigma$ confidence level; Fig. 14).

The St-Renan-Kersaint granite (LE 20) has been sampled in a quarry west of Brest (N $\left.48^{\circ} 25^{\prime} 9^{\prime \prime} / \mathrm{W} 4^{\circ} 38^{\prime} 33.6^{\prime \prime}\right)$. The size of nine monazite nonzoned grains included in biotite and muscovite ranges from 30 to $100 \mu \mathrm{m}$. The spread of the data is quite large, which lead to a narrow error envelope and subsequently rather precise age intercepts. They are similar within errors, since the $\mathrm{U}-\mathrm{Pb}$ age (intercept with $\mathrm{U}-\mathrm{Pb}$ axis) and the $\mathrm{Th}-\mathrm{Pb}$ age (intercept with $\mathrm{Th}-$ $\mathrm{Pb}$ axis) are at $320+25 /-26$ and $322 \pm 9 \mathrm{Ma}$, respectively. In other words, the regression line $(\mathrm{MSWD}=1.1$ for 81 analyses) fits perfectly with the theoretical isochron at $321 \mathrm{Ma}$. Monazite grains yield a mean age of $321 \pm 5 \mathrm{Ma}$ (at $2 \sigma$ confidence level; Fig. 15).

\section{Zircon LA-ICP-MS age of Le Conquet gabbro sample LE 04}

After a density separation of heavy minerals, hand-picked zircon grains were mounted in epoxy block, polished to obtain an even surface. Cathodoluminescence (CL) imaging was performed at the University of Sciences and Technologies of Lille (UMR 8110 PBDS) with a scanning electron microscope Quanta 200 (FEI, US). Analyses on single grains were made using the Neptune MC-ICP-MS (ThermoElectron, Bremen, Germany) at BRGM (Orléans, France) equipped with a multi-ion counting system, allowing a very high sensitivity (Cocherie and Robert 2007), and a laser ablation system (new wave frequency-quintupled Nd:YAG UV laser, distributed by VG, UK) operating at $213 \mathrm{~nm}$. The crater was $20 \mu \mathrm{m}$ in diameter and 15$20 \mu \mathrm{m}$ deep. Argon gas was used as carrier gas. Zircon standard used is 91500. Standard bracketing was applied to correct both elemental fractionations during the ablation process and mass bias originating from the MC-ICP-MS itself. Detailed instrumentation and analytical accuracy description are given in Cocherie et al. (2007) and Cocherie and Robert (2008). Tera and Wasserburg's (1972) diagram was made using Isoplot/Ex (3.1) of Ludwig (2004). 
Zircon grains are limpid, slightly pinky, and most of the time asymmetric, deformed, and with cracks. CL pictures showed two populations, one with a low CL (Fig. 16b), homogeneous unzoned or rarely slightly zoned, and the second with a higher CL (Fig. 16a) but often showing concentric or subconcentric growth zonations. Analyses data are given in Table 1.

On the Tera and Wasserburg's (1972) diagram (Fig. 16), two populations can be distinguished. The first one is characterized by a mean ${ }^{238} \mathrm{U} /{ }^{206} \mathrm{~Pb}$ ratio of $8.5 \pm 0.37$ and a mean ${ }^{207} \mathrm{~Pb} /{ }^{206} \mathrm{~Pb}$ ratio of $0.0571 \pm 0.0021$. These analyses show relatively low $\mathrm{U}, \mathrm{Th}$, and $\mathrm{Pb}$ concentrations and correspond mainly to the light CL zircons population, or cracked zircons. We interpret these analyses as a result of loss of $\mathrm{U}$ and a small amount of common $\mathrm{Pb}$ for the two points above the Concordia.

The analyses $(n=8)$ of the second population give concordant ellipses. However, three of them are significantly shifted indicating a slight radiogenic $\mathrm{Pb}$ loss. Thus, only five analyses were considered in the calculation of the mean ${ }^{238} \mathrm{U} /{ }^{206} \mathrm{~Pb}$ age of $478 \pm 4 \mathrm{Ma}$.

\section{Discussion of the geochronological data}

Our radiometric results confirm the relative chronology proposed above. In the biotitegarnet-staurolite micaschist of the Le Conquet metamorphic series (LE 05), monazite appears either as inclusion in biotite or along the biotite grain boundaries. These textural observations indicate that monazite crystallized during the intermediate pressure-intermediate temperature metamorphism. Thus, the approximate $340 \mathrm{Ma} \mathrm{U}-\mathrm{Th} / \mathrm{Pb}$ age can be considered as the age of the regional metamorphism. The close similarities between the monazite $\mathrm{U}-\mathrm{Th} / \mathrm{Pb}$ ages of the migmatites and anatectic granite indicate that crustal melting took place around 335-325 Ma. The $321 \pm 5 \mathrm{Ma}$ age of the St-Renan pluton appears slightly younger than the migmatization; however, the migmatite and granite yield the same age in the error limit. Thus, the genesis of the magma source of the St-Renan granite can be due to the same thermal event responsible for crustal melting.

The approximate $480 \mathrm{Ma}$ age of the Le Conquet gabbro is close to that of the Brest orthogneiss. At the scale of the entire French Variscan Belt, Ordovician is acknowledged as the time when the northern margin of Gondwana experienced rifting responsible for the separation of several microcontinents such as Armorica and Avalonia (e.g., Matte 2001; Faure et al. 2005). Several alkaline or calcalkaline granitic plutons and mafic rocks (gabbro, diorite) were emplaced during this crustal thinning. These rocks were subsequently transformed into orthogneiss and metagabbro during Variscan tectonics. In the study area, the Brest orthogneiss probably belongs to the magmatic rocks formed in such an extensional setting. The mafic rocks of the Penzé-Le Conquet nappe might also be emplaced during the Ordovician rifting episode.

On the basis of field observation, the age of the synmetamorphic top-to-the-N (or NW) ductile shearing, coeval with nappe stacking in the Léon Block, is older than the anatexis dated here at 335-325 Ma and younger than the Devonian rocks involved in the deformation in the Penzé area (Fig. 7). Our monazite $\mathrm{U}-\mathrm{Th} / \mathrm{Pb}$ age of $338 \pm 5 \mathrm{Ma}$ (i.e. Visean) is in agreement with this geological conclusion. Another ductile event is the dextral shearing along the NASZ and Elorn wrench faults (Figs. 3, 4). As observed in the Le Conquet area, the wrenching overprints the top-to-the-N shearing. In agreement with previous conclusions (e.g., Gore and Le Corre 1987; Le Corre et al. 1989; 1991; Rolet et al. 1994), the age of the dextral shearing can be inferred from that of the synkinematic St-Renan pluton. Our monazite $\mathrm{U}-\mathrm{Th} / \mathrm{Pb}$ dating 
indicates that the NASZ was active at about $320 \mathrm{Ma}$ (Fig. 9). Moreover, the HP metamorphism is dated at about $440 \mathrm{Ma}$ (Paquette et al. 1987). Such a large time span of about 100 Ma between the HP metamorphism and crustal melting appears as quite unusual in orogens. Thus, even if the chronological data are correct, the Carboniferous metamorphism and crustal melting cannot be interpreted as a thermal and structural response of the exhumation of the HP rocks. However, the possibility of a younger age for the HP metamorphism remains an eventuality to be tested in forthcoming works.

\section{The place of the Léon Domain within the Variscan framework Possible geodynamic evolution of the Léon Domain}

The Intermediate Nappe, composed of Penzé-Le Conquet micaschists and mafic rocks, and the Lower Nappe made of gneiss and eclogites, have been interpreted as relics of a suture zone separating the Léon and the North-Central Armorican domains (Fig. 2; Rolet et al. 1994; Faure et al. 2005). However, these rocks are not similar to typical ophiolitic suites, since mafic and ultramafic rocks are rare and true radiolarites are not recognized. Nevertheless, the geochemistry of the eclogites indicates that they are oceanic tholeiites formed in an oceanic basin (Cabanis and Godard 1987; Paquette et al. 1987). Thus, in spite of still poorly documented paleogeographic or geochemical constraints, it is possible that the Léon Domain and the North-Central Armorican Domain were separated by an oceanic basin or at least by a rift underlain by thinned continental crust. During the Variscan tectonics, the Léon Domain was overthrust to the North by the North-Central Armorican Domain. In this case, the PenzéLe Conquet micaschists and mafic rocks could be interpreted as a suture separating the two domains. Nevertheless, the width of the oceanic domain remains unknown. A wide oceanic area has been speculated (Faure et al. 2005), but a smaller basin similar to the Brévenne basin that developed in Devonian in the eastern Massif Central (Fig. 1; Ledru et al. 1989; Leloix et al. 1999) is also possible.

The Léon Domain has also been considered as an "exotic terrane" initially belonging to the Upper Gneiss Unit of the South Armorican Domain and translated to the north by the Elorn strike-slip fault (Balé and Brun 1986; Le Corre et al. 1989). However, as already pointed out (Rolet et al. 1986, 1994; Faure et al. 2005), such an interpretation does not match the available structural data. In the Penzé area, at the northeastern termination of the Léon Domain, such a strike-slip fault is not recognized (Fig. 7). Conversely, the pervasive lowangle S- or SE-dipping foliation and NNW-SSE to E-W trending lineation show that the Central Armorican Domain has been overthrust onto the Léon Domain (Fig. 8). Therefore, the Penzé-Le Conquet Intermediate Nappe is rooted below the North-Central Armorican Domain. Obviously, in Le Conquet, the root zone was reworked along NE-SW-trending dextral wrench faults, which keep an E-W trend to the east but do not reach the Penzé area.

The northern limit of the Léon Domain is presently hidden below the sea. A gravity and magnetic anomaly that occupies the central part of the Channel is interpreted as the Rheic suture (Bois et al. 1994; Fig. 1). Several seismic lines through the Channel indicate dominantly south-dipping reflectors (Le Gall 1990). In particular, the ophiolitic nappe that crops out in the Lizard Point is dipping southward below crystalline rocks interpreted as the offshore extension of the Léon Domain. The Léon Domain appears as a continental block bounded by the Rheic and Le Conquet sutures on the north and south. Both sutures are distinct from the Eo-Variscan suture that separates the North-Central Armorican and the South Armorican domains. A simplified, crustal scale tectonic interpretation of the Massif 
Armoricain is depicted in Fig. 17. In this cross section, the late orogenic granitic plutons are not represented to emphasize the earlier structures.

\section{Possible extension of the Mid-German Crystalline Rise}

As the Léon Domain is not an "exotic terrane" displaced from the south, its equivalent must be located east of the Paris Basin (Fig. 1). In Central Europe, it is well acknowledged that the Ardenne Massif belongs to the Rheno-Hercynian Zone, which is the southern continental margin of Laurussia. The southern boundary of the Rheno-Hercynian Zone is represented by the Northern Phyllite Zone (NPZ), where a Carboniferous high-pressure metamorphism is associated with north-directed thrusting. South of the NPZ, the Paleozoic rocks that crop out in the Spessart and Odenwald massifs are parts of a microcontinent called the Mid-German Crystalline Rise (MGCR, e.g., Holder and Leveridge 1986; Hirschmann and Okrusch 1988; Oncken 1997; Altherr et al. 1999; Franke 2000; Will and Schmädicke 2001 and enclosed references).

In spite of a large lithological diversity and structural complexity, the MGCR contains Ordovician orthogneiss, Devonian-Carboniferous arc magmatic rocks, HT metamorphic and migmatitic rocks. Eclogites have also been recognized in the Odenwald Massif (Will and Schmädicke 2001). Farther south, the Saxothuringian basin separates the MGCR from the Tepla-Barrandian Zone that is correlated with the North-Central Armorican domain, both of them belonging to the Armorica microcontinent (Fig. 1; Franke 2000; Matte 2001). In this framework, the Léon Domain could be correlated with the MGCR (Fig. 1; Cabanis et al. 1979, Faure et al. 2005). Since the northern part of the Léon Domain is hidden below the sea, the limited surface exposure does not allow us to recognize subduction-related rocks as described in the Odenwald and Spessart massifs that would lie more to the north, and thus closer to the subduction zone (Oncken 1997; Franke 2000).

The boundary between the MGCR and Laurussia (i.e. Rheno-Hercynian Zone) corresponds to the Rheic or Rheno-Hercynian Suture, depending on authors (e.g., Franke 2000; Matte 2001). The continuation between the Rheic Suture and the NPZ is hidden below the Paris Basin and was possibly offset left-laterally along the Bray fault (Matte 1986; 2001). This correlation is supported by seismological, gravimetric, and magnetic data (Matte and Hirn 1988; Edel and Weber 2004). The boundary between the MGCR and Armorica does not crop out in Central Europe, except in the Bohemian Massif. A complete discussion of these elements is beyond the scope of this paper [see Franke (2001) for a comprehensive review].

\section{Conclusion}

The Léon Domain appears to be a microcontinent separated from Armorica in Early Ordovician time. This is suggested by the Brest orthogneiss and the mafic rocks observed in the Le Conquet and Penzé areas. The Léon microcontinent was rewelded to Armorica after a south-directed subduction coeval with high-pressure metamorphism, the age of which remains poorly constrained. The Léon Domain experienced a MP/MT metamorphism dated here at about $340 \mathrm{Ma}$ by the EPMA method. The stack of the metamorphic nappes was subsequently folded into an antiform and experienced a HT metamorphism and crustal melting at about 335-327 Ma before the dextral strike-slip faulting along the North Armorican Shear Zone and the Elorn fault. Within the European Variscan framework, the Léon Domain is correlated with metamorphic and plutonic massifs of the MGCR. As a whole, the MGCR and its possible westward extension can be interpreted as a continental strip that separated from the Amorica 
microcontinent in the Early Ordovician. The oceanic or continental nature and the width of the area that separated Armorica and MGCR cannot be determined in the Léon area. Although less studied than Avalonia or Armorica, the MGCR probably played an important role in the complex plate tectonic evolution leading to the formation of the Variscan orogen.

Acknowledgments LA ICP MS analyses have been supported by the program "Cartographie géologique de la France au 1/50000" directed by P. Rossi in BRGM (Orléans, France).

Constructive reviews by G. Eisbacher, M. Sintubin, and R. Greiling are greatly acknowledged.

\section{References}

Altherr R, Henes-Klaiber U, Hegner E, Satir M, Langer C (1999) Plutonism in the Variscan Odenwald (germany): from subduction to collision. Int J Earth Sci 88:422-443. doi: $10.1007 / \mathrm{s} 005310050276$

Balé P, Brun JP (1986) Les complexes métamorphiques du Léon (NW Bretagne): un segment du domaine éo-hercynien sud armoricain translaté au Dévonien Bull. Soc Geol Fr 2:471-477

Ballèvre M, Marchand J, Godard G, Goujou JC, Wyns R (1994) Eo-Hercynian events in the Massif Armoricain. In: Keppie JD (ed) Pre-Mesozoic geology of France and related areas. Springer, Berlin, pp 183-194

Be Mezème E, Faure M, Cocherie A, Chen Y (2005) In situ chemical dating of tectonothermal events in the French Variscan Belt. Terra Nova 17:420-426. doi:10.1111/j.1365-3121.2005.00628.x

Bois C, Cazes M, Choukroune P, Garrel O, Hirn A, Le Gall B et al (1994) Seismic reflection images of the Pre-Mesozoic crust in France and adjacent areas. In: Keppie JD (ed) PreMezozoic geology of France and related areas. Springer, Berlin, pp 3-48

Braun I, Montel JM, Nicollet C (1998) Electron microprobe dating of monazite from highgrade gneisses and pegmatites of Kerala Khondalite Belt, Southern India. Chem Geol 146:6585. doi:10.1016/S0009-2541(98)00005-9

Cabanis B, Godard G (1987) Les éclogites du pays de Léon (nord-Ouest du Massif armoricain): étude pétrologique et géochimique; implications géodynamiques. Bull Soc Geol Fr 6:1133-1142

Cabanis B, Peucat J, Michot J, Deutsch S (1979) Remise en cause de l'existence d'un socle orthogneissique antécambrien dans le pays de Léon (domaine Nord-armoricain); étude géochronologique par les méthodes $\mathrm{Rb} / \mathrm{Sr}$ et $\mathrm{U} / \mathrm{Pb}$ des orthogneiss de Tréglonou et de Plouvenez-Lochrist. Bull BRGM 4:357-364

Chauris L, Hallégouet B (1989) Carte géologique de France 1/50.000 et notice explicative, feuille Le Conquet, BRGM, Orléans, 69 pp

Chauris L, Marcoux E, Le Goff E, Thiéblement D, Carn A (1998) Carte géologique de France 1/50.000 et notice explicative, feuille Saint-Pol de Léon, BRGM, Orléans, 167 pp 
Cocherie A, Albarède F (2001) An improved U-Th-Pb age calculation for electron microprobe dating of monazite. Geochim Cosmochim Acta 65:4509-4522.

doi:10.1016/S0016-7037(01)00753-0

Cocherie A, Legendre O (2007) Potential minerals for determining U-Th-Pb chemical age using electron microprobe. Lithos 93(3/4):288-309. doi:10.1016/j.lithos.2006.03.069

Cocherie A, Robert M (2007) Direct measurement of lead isotope ratios in low concentration environmental samples by MC-ICP-MS and multi-ion counting. Chem Geol 243:90-104. doi:10.1016/j.chemgeo.2007.05.011

Cocherie A, Robert M (2008) Laser ablation coupled with ICP-MS applied to U-Pb zircon geochronology: a review of recent advances. Gondwana Res Special Issue (in press)

Cocherie A, Legendre O, Peucat JJ, Kouamelan AN (1998) Geochronology of polygenetic monazites constrained by in situ electron microprobe U-Th-total lead determination: implications for lead behaviour in monazite. Geochim Cosmochim Acta 62:2475-2497. doi:10.1016/S0016-7037(98)00171-9

Cocherie A, Be Mezème E, Legendre O, Fanning CM, Faure M, Rossi P (2005) Electronmicroprobe dating as a tool for determining the closure of Th- $\mathrm{U}-\mathrm{Pb}$ systems in migmatitic monazites. Am Mineral 90:607-618. doi:10.2138/am.2005.1303

Cocherie A, Fanning CM, Jezéquel P, Robert M (2007) LA-MC-ICPMS applied to in situ U$\mathrm{Pb}$ dating of $2 \mathrm{Ma}$ zircons using a multi-ion counting system. Electron microscopy and microanalysis conference. In: Mineralogical Society of Poland-special papers 30. Mineralogical Society of Poland, Krakow, pp 61-63

Cogné J (1974) Le Massif Armoricain. In: Debelmas J (ed) Géologie de la France. Doin, Paris, pp 105-161

Deutsch S, Chauris L (1965) Age de quelques formations cristallophylliennes et granitiques du Pays de Léon (Finistère). C R Acad Sci Paris 260:615-617

Edel JB, Weber K (2004) Cadomian terranes, wrench faulting and thrusting in the central Europe Variscides: geophysical and geological evidence. Int J Earth Sci 84:412-432

Faure M, Bé Mézème E, Duguet M, Cartier C, Talbot J (2005) Paleozoic tectonic evolution of Medio-europa from the example of the French Massif Central and Massif Armoricain. In: Carosi R, Dias R, Iacopini D, Rosenbaum G (eds) The southern Variscan belt. J Virt Explor, electronic edition, ISSN 1441-8142, vol 19, paper 5

Franke W (2000) The Mid-European segment of the Variscides: tectonostratigraphic units, terrane boundaries and plate tectonic evolution. In: Franke W, Haak V, Oncken O, Tanner D (eds) Quantification and modelling in the Variscan Belt (Geological Society of London special publication 179). Geological Society, London, pp 21-34

Goré B, Le Corre C (1987) Cinématique hercynienne du cisaillement nord-armoricain à la bordure du granite syntectonique de St Renan-Kerstaint (Finistère). Bull Soc Geol Fr 5:811819 
Holder MT, Leveridge BE (1986) Correlation of the Rhenohercynian Variscides. J Geol Soc Lond 143:141-147. doi:10.1144/gsjgs.143.1.0141

Hirschmann G, Okrusch M (1988) The Spessart and the Ruhla crystalline complexes as constituent of the central German Crystalline Rise - a correlation. Neues Jahrb Geol Palaontol Abh 177:1-39

Le Corre C, Balé P, Geoget Y (1989) Le Léon: un domaine exotique au Nord-Ouest de la chaîne varisque armoricaine. Geodin Acta 3:57-71

Le Corre C, Auvray B, Ballevre M, Robardet M (1991) Le Massif Armoricain. Sci Geol Bull $44: 31-103$

Ledru P, Lardeaux JM, Santallier D, Autran A, Quenardel JM, Floc'h JP, Lerouge G, Maillet N, Marchand J, Ploquin A (1989) Où sont les nappes dans le Massif Central français? Bull Soc Geol Fr 8:605-618

Le Gall B (1990) Evidence of an imbricate crustal thrust belt in the southern British Variscides. Contribution of SWAT deep sismic reflection profiling recorded in the English Channel and the Celtic Sea. Tectonics 9:283-302. doi:10.1029/TC009i002p00283

Leloix C, Faure M, Feybesse JL (1999) Hercynian polyphase tectonics in north-east French Massif Central: the closure of the Brévenne Devonian-Dinantian rift. Int J Earth Sci 88:409421. doi: $10.1007 / \mathrm{s} 005310050275$

Leutwein F, Chauris L, Sonet J, Zimmermann JL (1969) Etudes géochronologiques et géotectoniques dans le Nord-Finistère (Massif Armoricain). Sci Terre 14:331-358

Ludwig KR (2004) Users manual for ISOPLOT/EX, version 3.1. A geochronological toolkit for Microsoft Excel Berkeley Geochronology Center, Special Publication, vol 4

Marchand J (1981) Ecaillage d'un "mélange tectonique" profond: le complexe cristallophyllien de Champtoceaux (Bretagne Méridionale). C R Acad Sci Paris II 293:223228

Matte P (1986) La chaîne Varisque parmi les chaînes Paléozoïques périatlantiques, modèle d'évolution et position des grands blocs continentaux au Permo-Carbonifère. Bull Soc Geol Fr 2:9-24

Matte P (2001) The Variscan collage and orogeny (480-290 Ma) and the tectonic definition of the Armorica microplate: a review. Terra Nova 13:122-128. doi:10.1046/j.13653121.2001.00327.x

Matte P, Hirn A (1988) Généralités sur la chaîne varisque d'Europe, coupe complete de la chaîne sous l'Ouest de la France, Programme ECORS Profil Nord de la France. Technip, Paris, pp 197-222 
Montel JM, Forest S, Veschambree M, Nicollet C, Provost A (1996) Electron microprobe dating of monazite. Chem Geol 131:37-53. doi:10.1016/0009-2541(96)00024-1

Montel JM, Kornprobst J, Vielzeuf D (2000) Preservation of old U-Th-Pb ages in shielded monazite: example from Beni Bousera Hercynian Kinzigites (Morroco). J Metamorph Geol $18: 335-342$

Oncken O (1997) Transformation of a magmatic arc and an orogenic root during oblique collision and its consequences for the evolution of the European Variscides (Mid-German Crystalline Rise). Geol Rundsch 86:2-20. doi:10.1007/s005310050118

Paquette JL, Balé P, Ballèvre M, Georget Y (1987) Geochronology et géochimie des eclogites du Léon: nouvelles contraintes sur l'évolution géodynamique du Nord-Ouest du Massif Armoricain. Bull Miner 110:683-696

Paris F, Robardet M (1990) Early Paleozoic paleobiogeography of the Variscan regions. Tectonophysics 177:193-213

Parrish RR (1990) U-Pb dating of monazite and its application to geological problems. Can J Earth Sci 27:1431-1450

Pin C (1990) Variscans oceans: ages, origins and geodynamic implications inferred from geochemical and radiometric data. Tectonophysics 177:215-227

Pommier A, Cocherie A, Legendre O (2002) EPMA dating users manual-age calculation from electron probe microanalyser measurements of $\mathrm{U}-\mathrm{Th}-\mathrm{Pb}$, internal report, BRGM, Orleans, $9 \mathrm{pp}$

Pyle JM, Spear FS, Rudnick RL, McDonough WF (2001) Monazite-xenotime-garnet equilibrium in metapelites and a new monazite-garnet thermometer. J Petrol 42:2083-2107

Robardet M (2003) The Armorica microplate: fact or fiction? Critical review of the concept and contradictory palaeobiogeographical data. Paleogeogr Palaeoclimatol Palaeoecol 195:125-148

Rolet J, Le Gall B, Darboux JR, Thonon P, Gravelle M (1986) L'évolution géodynamique dévono-carbonifère de l'extrémité occidentale de la chaîne hercynienne d'europe sur le transect Armorique-Cornwall. Bull Soc Geol Fr 8:43-54

Rolet J, Gresselin F, Jegouzo P, Ledru P, Wyns R (1994) Intracontinental Hercynian events in the Armorican Massif. In: Keppie JD (ed) Pre-Mezozoic geology of France and related areas. Springer, Berlin, pp 195-219

Schultz B, De Wall H, Finger F (2007) Continuous variscan deformation during granitoid intrusion in the Léon Domain (Armorican Massif, France). In: Mechanics of Variscan orogeny, September 13-15, 2007, BRGM, Orleans (special volume of Géologie de la France), vol 2, pp 155

Suzuki K, Adachi M (1991) The Chemical Th-U-total Pb isochron ages of zircon and monazite from the gray granite of Hida Terrane, Japan. J Earth Sci Nagoya Univ 38:11-37 
Tait J, Bachtadse V, Franke W, Soffel HC (1997) Geodynamic evolution of the European Variscan fold belt: palaeomagnetic and geological constraints. Geol Rundsch 86:585-598

Tera F, Wasserburg GJ (1972) U-Th-Pb systematics in three Apollo 14 basalts and the problem of initial Pb in lunar rocks. Earth Planet Sci Lett 14:281-304

Von Raumer J, Stampfli G, Borel G, Bussy F (2002) The organization of pre-Variscan basement areas at the north-Gondwana margin. Int J Earth Sci 91:35-52

Wendt I, Carl C (1991) The statistical distribution of the mean squared weighted deviation. Chem Geol 86:275-285

Will T, Schmädicke E (2001) A first find of retrogressed eclogites in the Odenwald Crystalline Complex, Mid-German Crystalline Rise, Germany: evidence for a so far unrecognized high-pressure metamorphism in the Central Variscides. Lithos 59:109-125

Williams ML, Jercinovic MJ (2002) Microprobe monazite geochronology: putting absolute time into microstructural analysis. J Struct Geol 24:1013-1028 


\section{Figures}

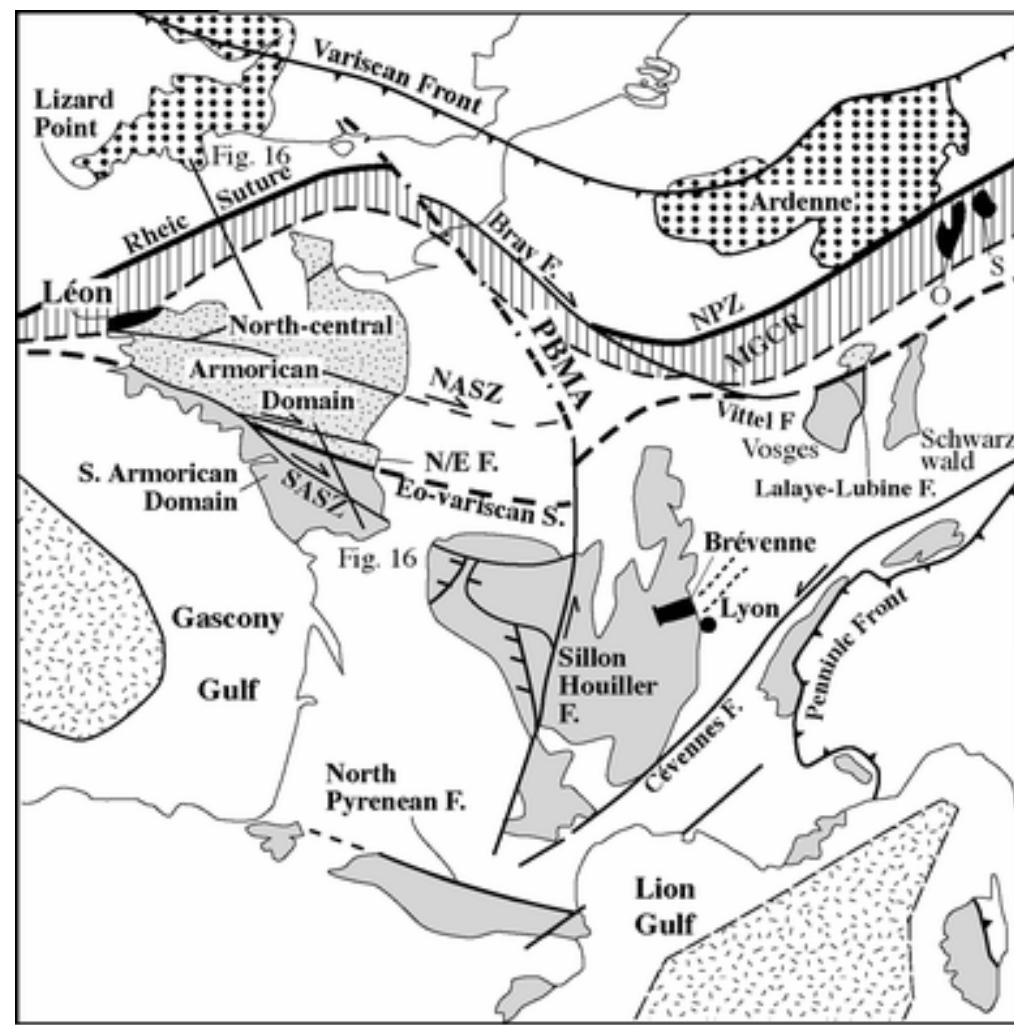

Rheno- Hercynian Zone of Laurussia (SW England, Ardenne)

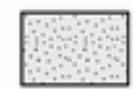

Armorica (North-central Armorican Domain)

Mid-German Crystalline Rise (MGCR), including Léon Domain, Odenwald North Gondwana margin: (O), Spessart (S)

S. Armorican Domain, Massif central, ...)

PBMA : Paris Basin Magnetic Anomaly

NPZ : North Phyllite Zone

Fig. 1 Tectonic map of the Variscan Belt of Western Europe with emphasis on the main suture zones, litho-tectonic domains, and location of the Léon Domain. NASZ North Armorican Shear Zone, SASZ South Armorican Shear Zone, N/E F Nort-sur-Erdre Fault 


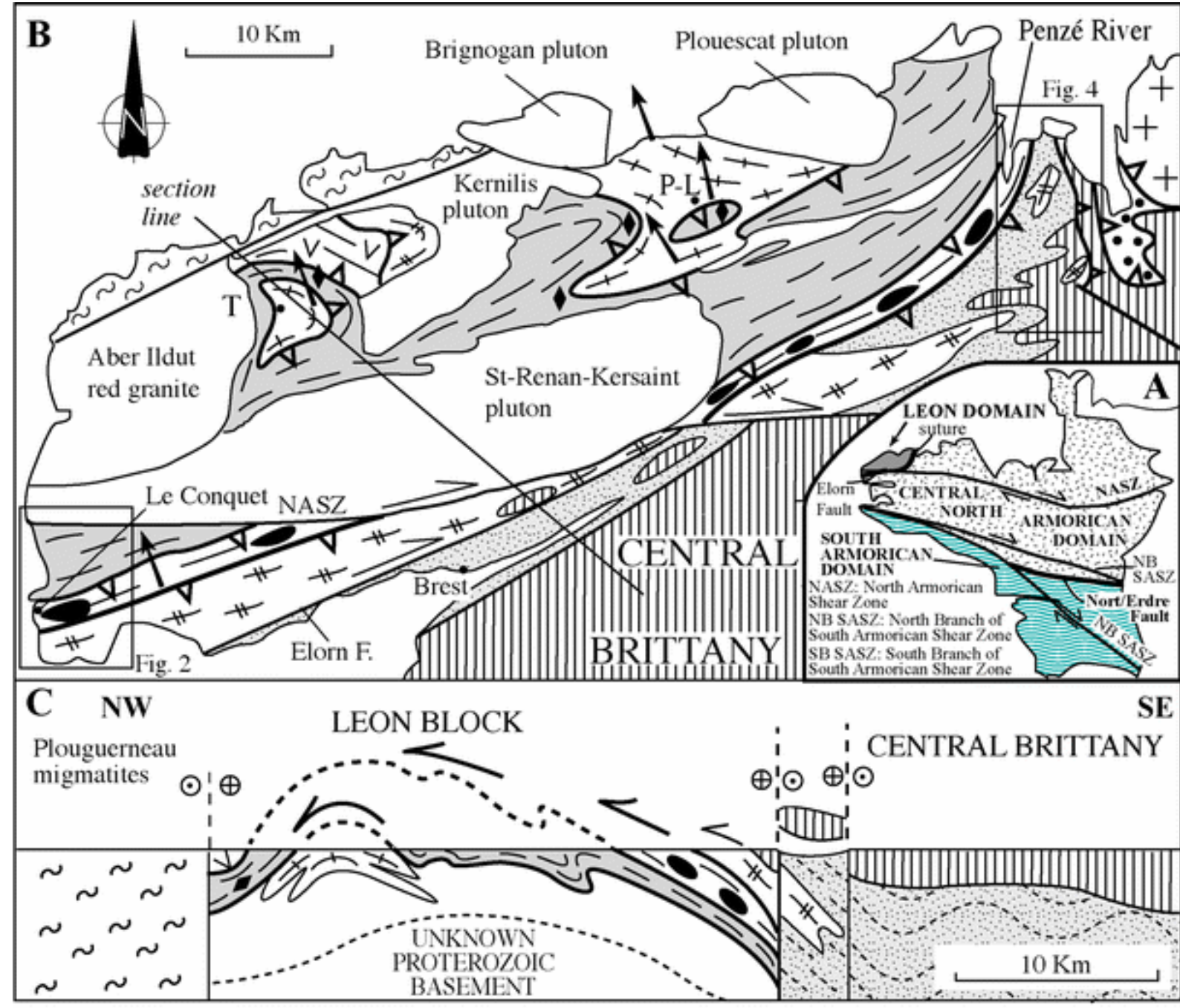

Intermediate Nappe Le Conquet-Penzé metabasites : ophiolites (?)

Lower Nappe: micaschists, gneiss and eclogite boudins ( $)$, partly migmatitic Para-autochthonous Unit : Tréglonou (T), Plounevez-Lochrist (PL) orthogneiss and host-rock paragneiss

$++\quad$ Neoproterozoic (Cadomian) basement of Trégor

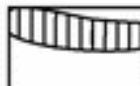

Upper Nappe : Paleozoic cover of Central Brittany

Armorica Basement: Proterozoic Elorn micaschists, Brest orthogneiss,

Stretching lineation with sense of shear of the upper part

Morlaix Carboniferous Bassin

NASZ : North Armorican Shear Zone

Fig. 2 Structural map and cross section of the Léon Domain showing the stack of nappes formed by top-to-the-N shearing: (a) subdivisions of the Massif Armoricain; (b) tectonic map; (c) section along the line located in (b) 


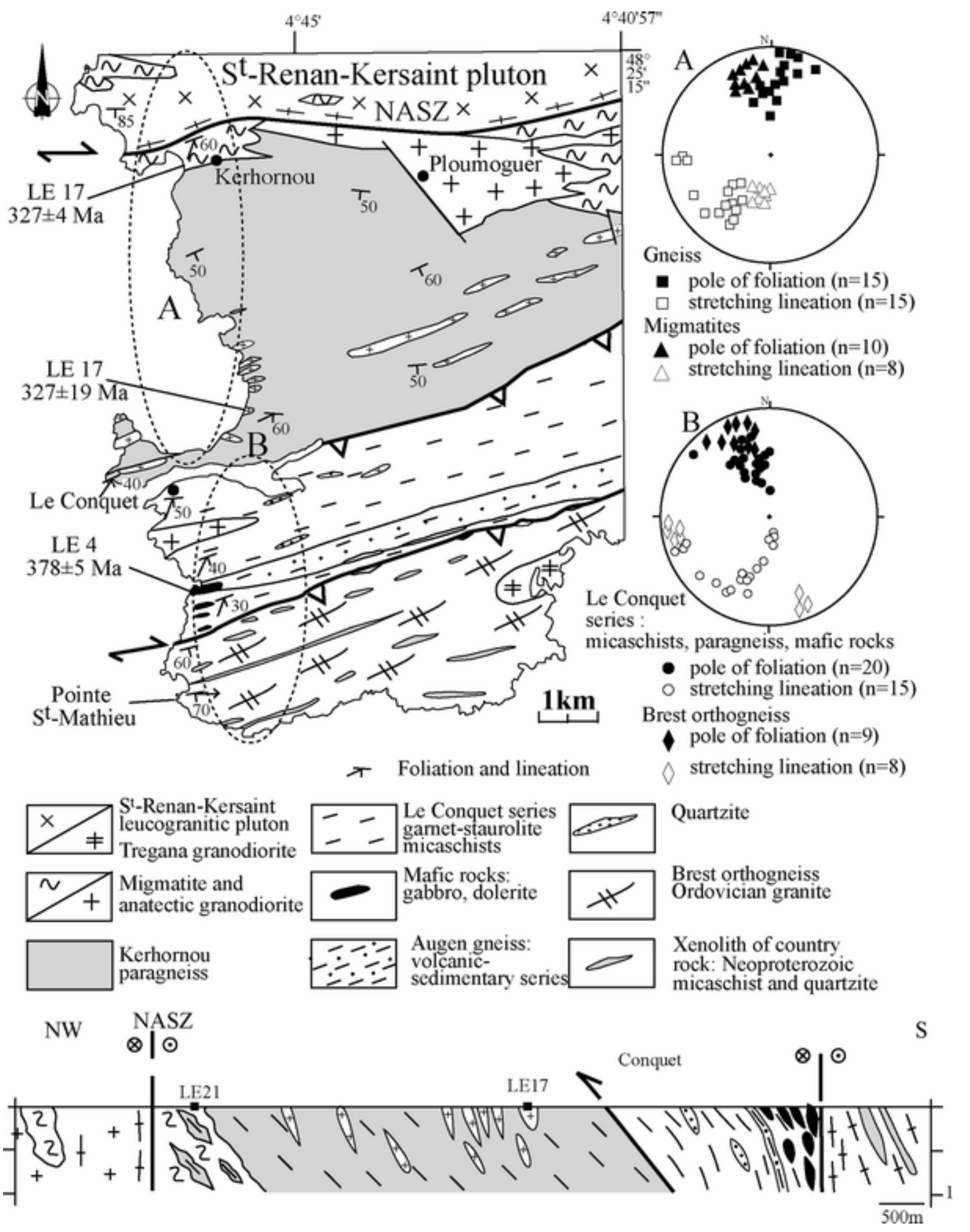

Fig. 3 Structural map of the Le Conquet area simplified from Chauris and Hallégouet (1989), with location of the dated samples. Simplified cross section showing the south-dipping foliation, and the gradual transition between the Kerhornou gneiss and migmatites. Stereograms (Schmidt projection, lower hemisphere) of the structural elements, (a) gneiss and migmatites, (b) Le Conquet micaschists and Brest orthogneiss 

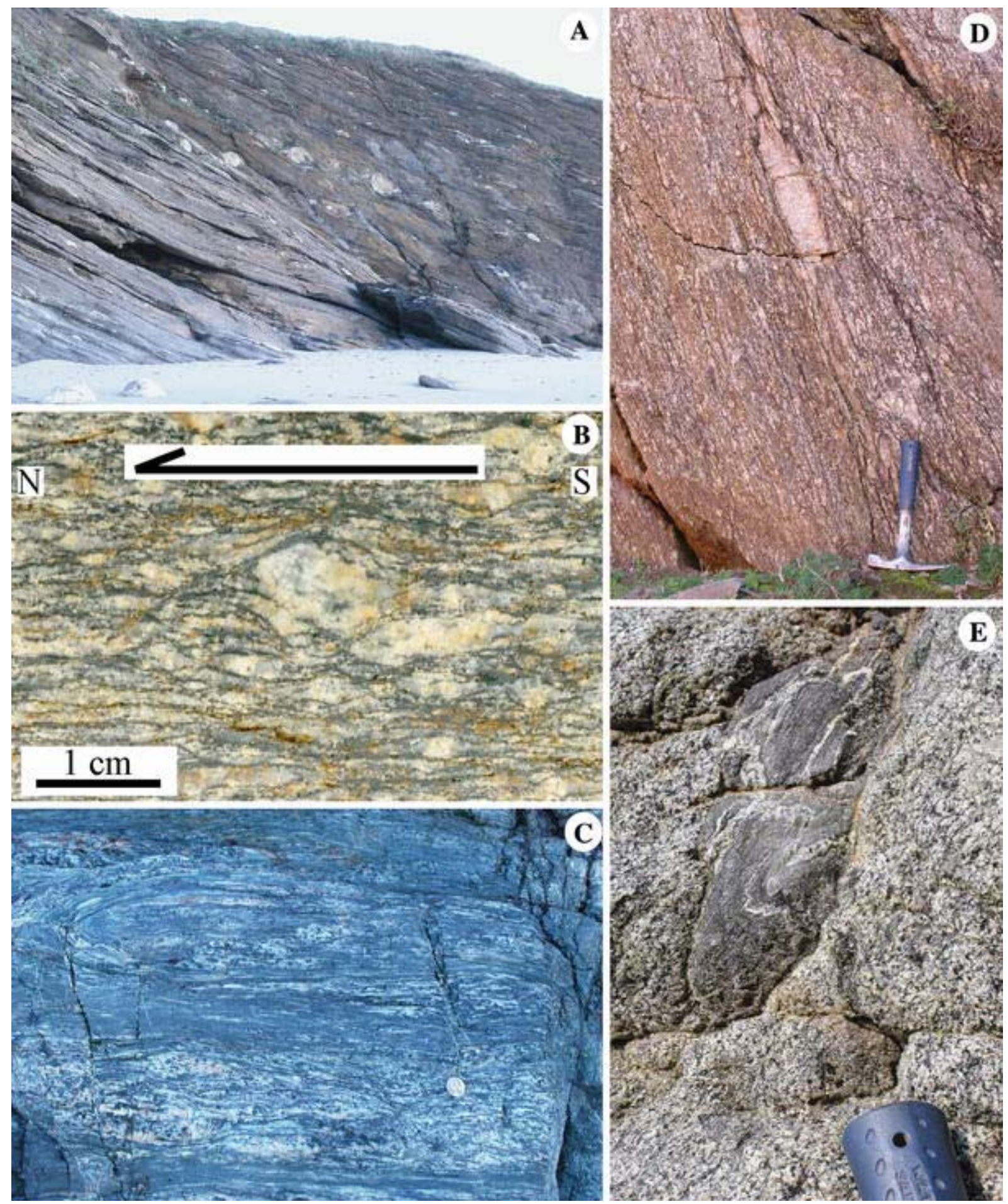

Fig. 4 Field photographs of Le Conquet area: (a) Le Conquet micaschists with abundant quartz veins; (b) asymmetric augen in the volcanic-sedimentary paragneiss of the Le Conquet series; (c) Mylonitic gabbro in Le Conquet; (d) Migmatite near Kerhornou; (e) Anatectic granite (sample LE 17) with xenolith of foliated and folded Kerhornou gneiss 

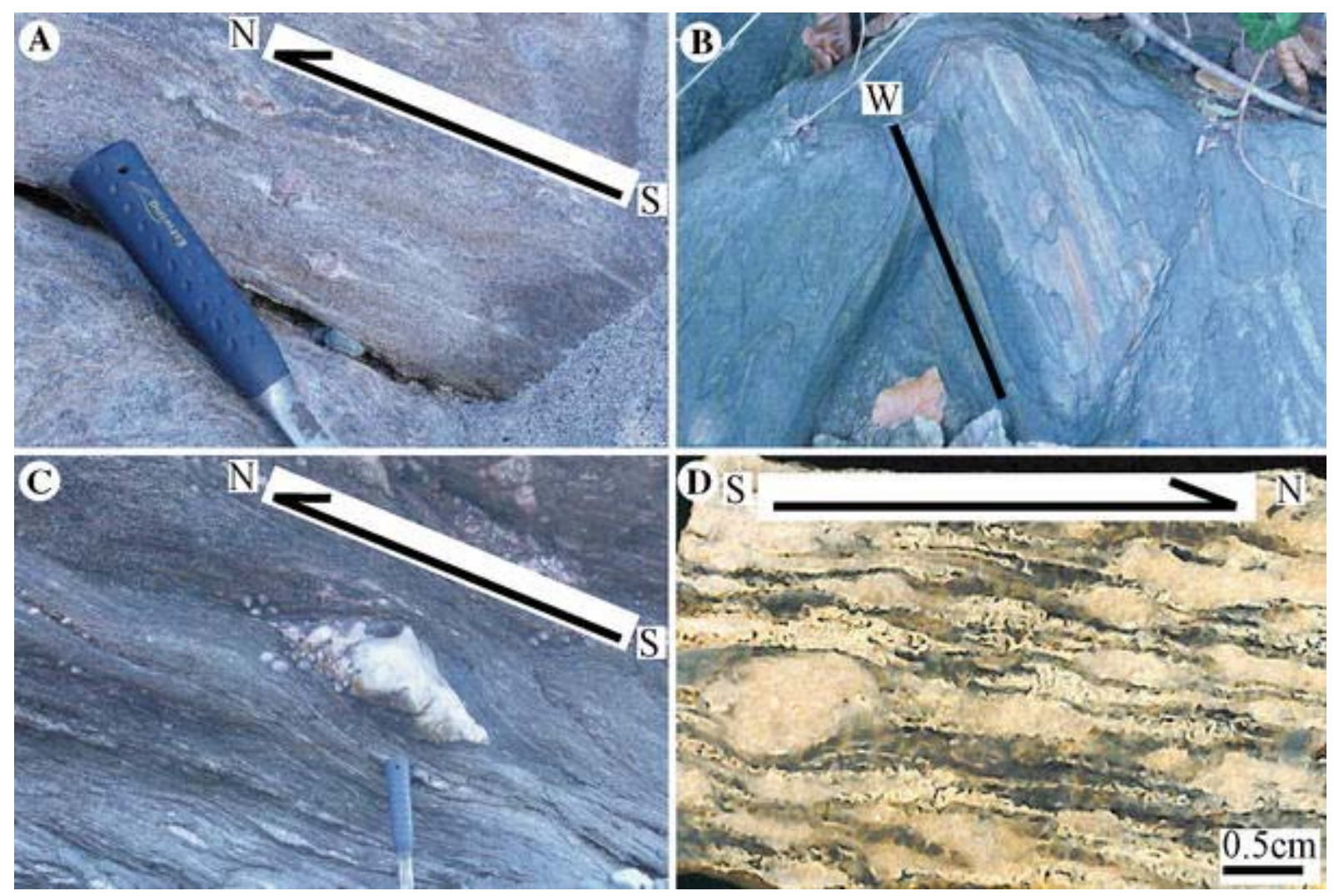

Fig. 5 Macroscopic structures: (a) centimeter-sized garnet porphyroblast with quartz pressure shadows in the Le Conquet micaschists, clast asymmetry indicates top-to-the-N shearing; (b) E-W trending stretching lineation in the Penzé micaschists; (c) top-to-the-N asymmetric quartz vein in Le Conquet micaschists; (d) Tréglonou augen orthogneiss with sigma-type porphyroclast systems indicating a top-to-the-N shearing 


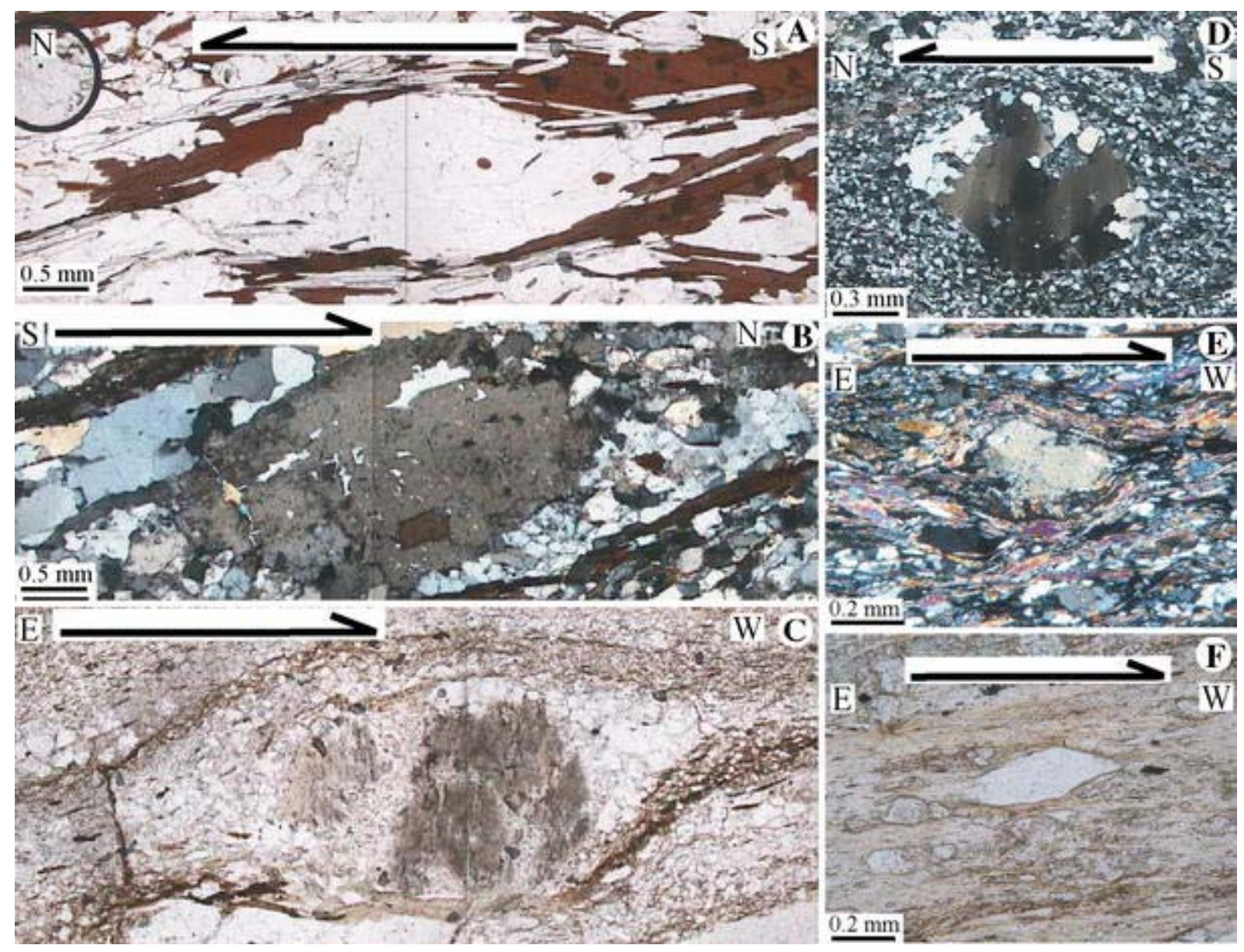

Fig. 6 Microscopic-scale kinematic indicators. a Sigma-type porphyroclast system in Kerhornou gneiss. b Asymmetric quartz pressure shadows around K-feldspar clast in Le Conquet paragneiss. c Sigma-type porphyroclast system with top-to-the-west shearing in Brest orthogneiss (Carantec, Penzé area). d Sigmoidal quartz clast in Le Conquet paragneiss. e Mylonitized amphibolite with shear bands and pressure shadows indicating a top-to-thewest shearing in Penzé metagabbro. f Sigmoidal clast in Devonian sandstone, East of Penzé 


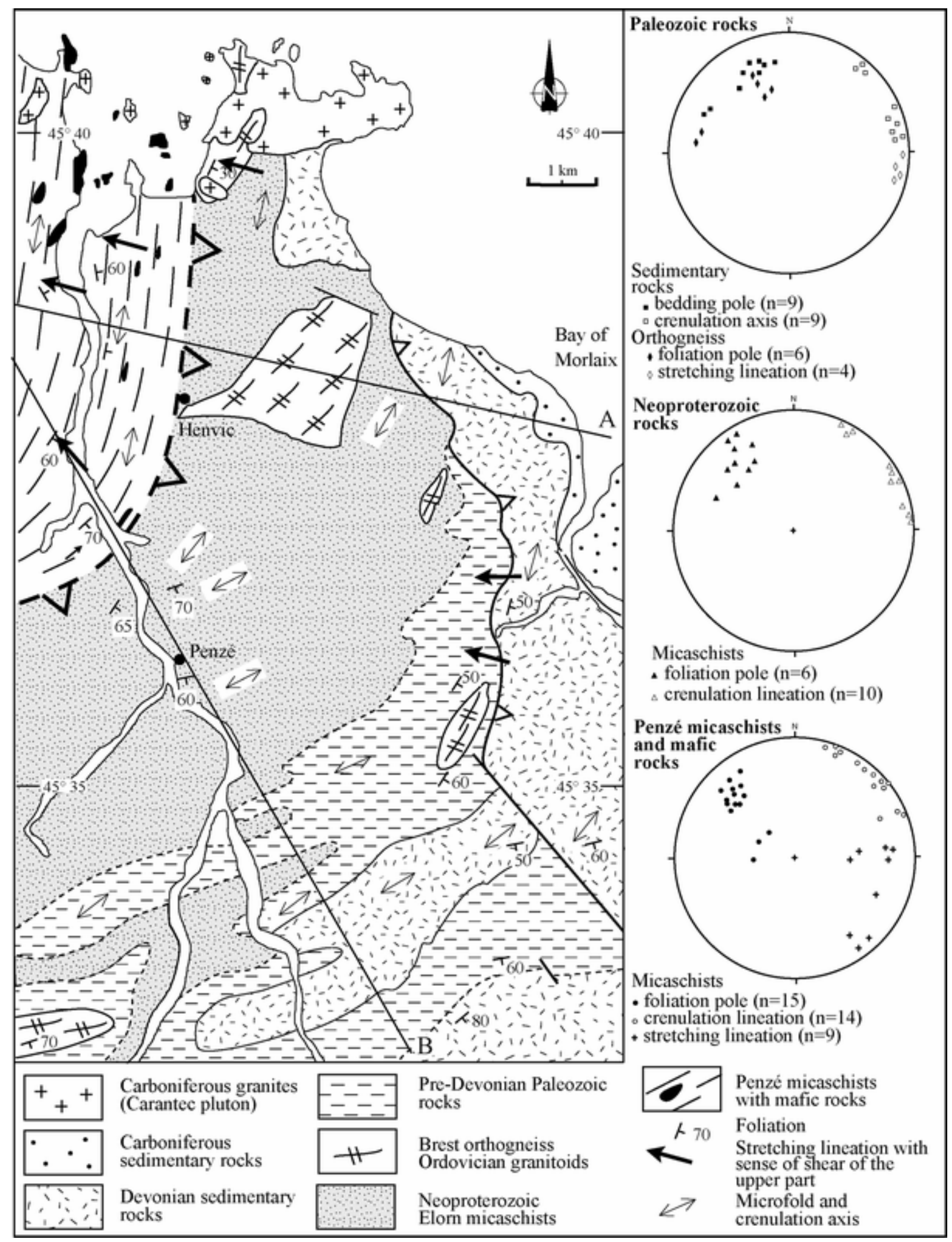

Fig. 7 Structural map of the Penzé area and stereograms (Schmidt projection, lower hemisphere) of the structural elements for Paleozoic sedimentary rocks and Brest orthogneiss, Neoproterozoic Elorn micaschists, and Penzé micaschists 


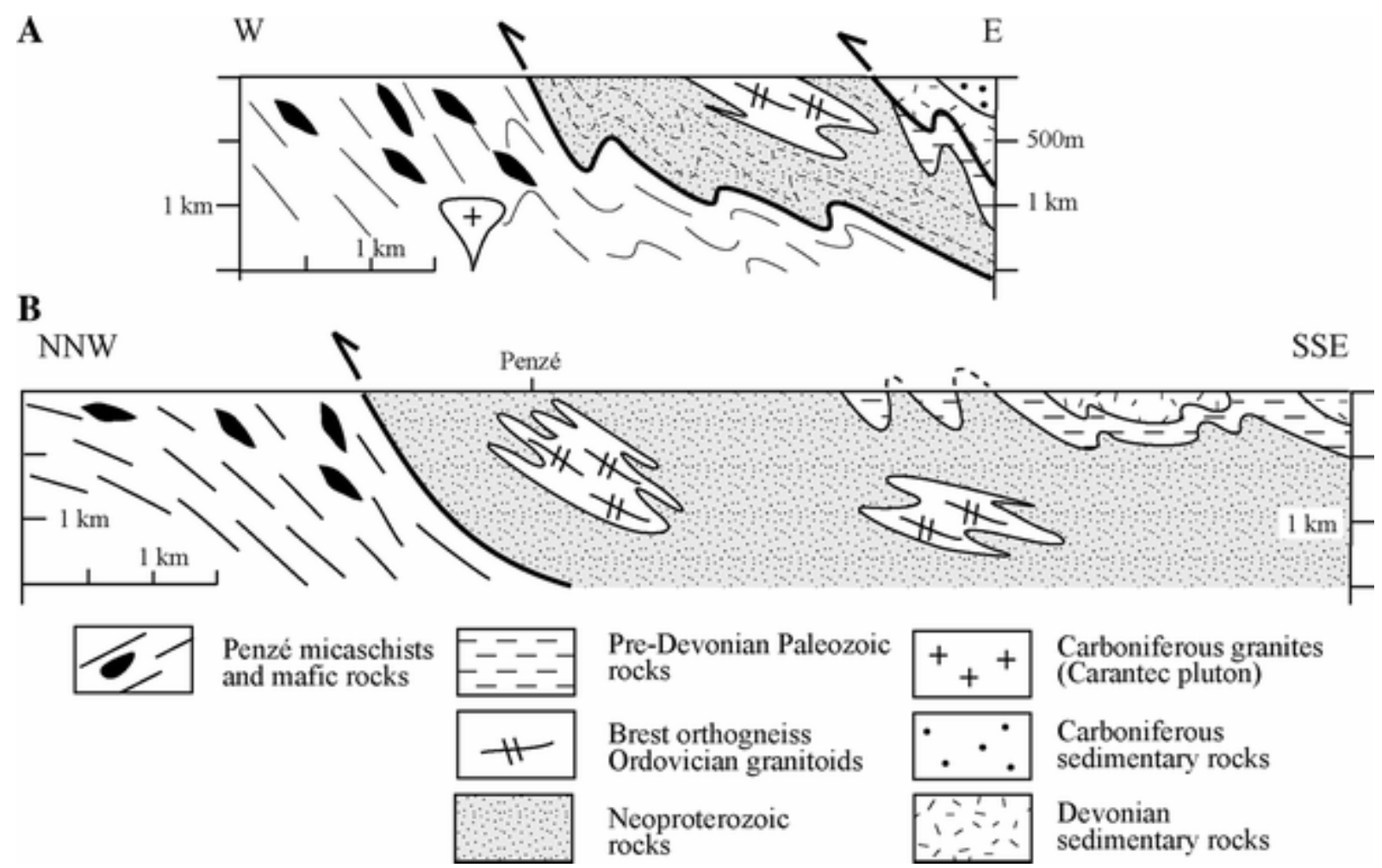

Fig. 8 Cross sections through the Penzé area (located in Fig. 7) showing the Westward displaced nappes 


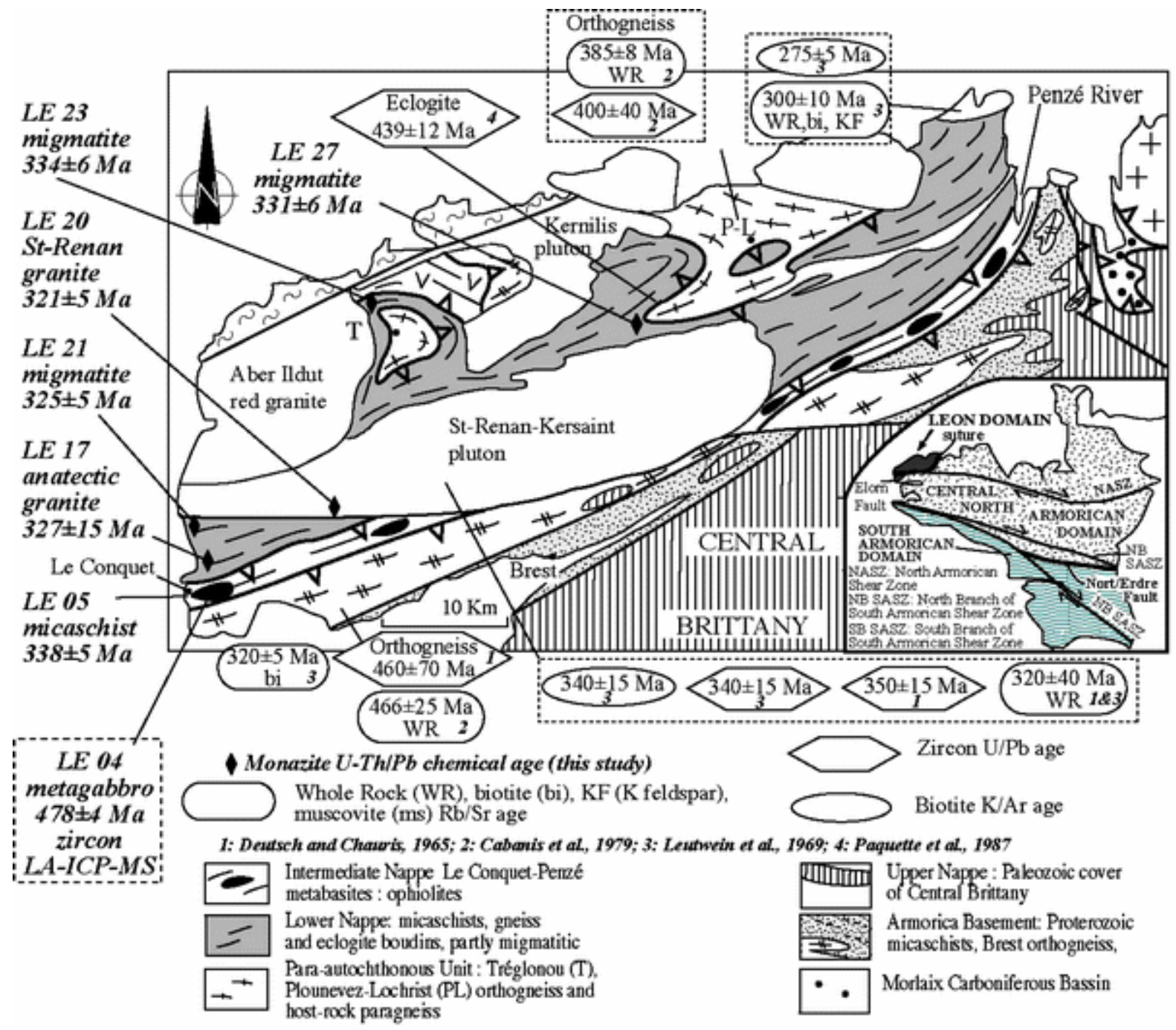

Fig. 9 Synthetic map of the Léon Domain with available radiometric ages (Deutsch and Chauris 1965; Leutwein et al. 1969; Paquette et al. 1987) and the new monazite $\mathrm{U}-\mathrm{Th} / \mathrm{Pb}$ chemical ages (this study) 


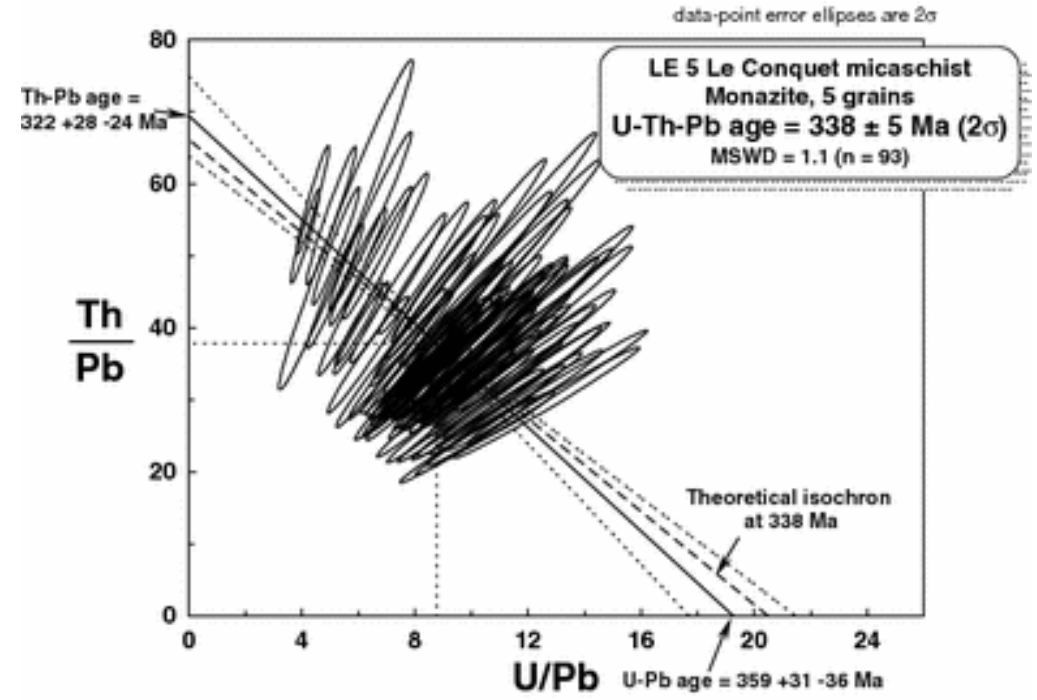

Fig. $10 \mathrm{Th} / \mathrm{Pb}$ versus $\mathrm{U} / \mathrm{Pb}$ isochron diagram for biotite-garnet-staurolite micaschist at Le Conquet LE 05. The data led to the calculated regression line (thick line), while the theoretical isochron (dashed line) must be included between the two error hyperbolas (thin lines). The condition to allow the mean age to be calculated at the centroid of the population: $338 \pm 5 \mathrm{Ma}$

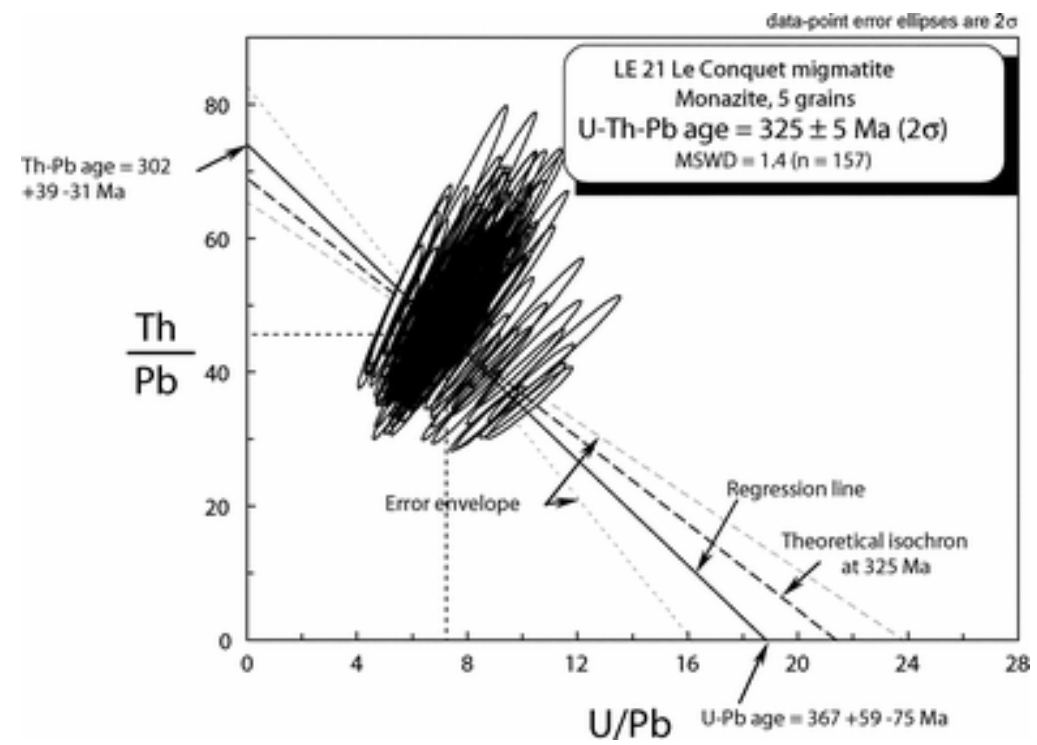

Fig. $11 \mathrm{Th} / \mathrm{Pb}$ versus $\mathrm{U} / \mathrm{Pb}$ isochron diagram for migmatite sample LE 21 . The data led to the calculated regression line (thick line), while the theoretical isochron (dashed line) must be included between the two error hyperbolas (thin lines). The condition to allow the mean age to be calculated at the centroid of the population: $325 \pm 5 \mathrm{Ma}$ 


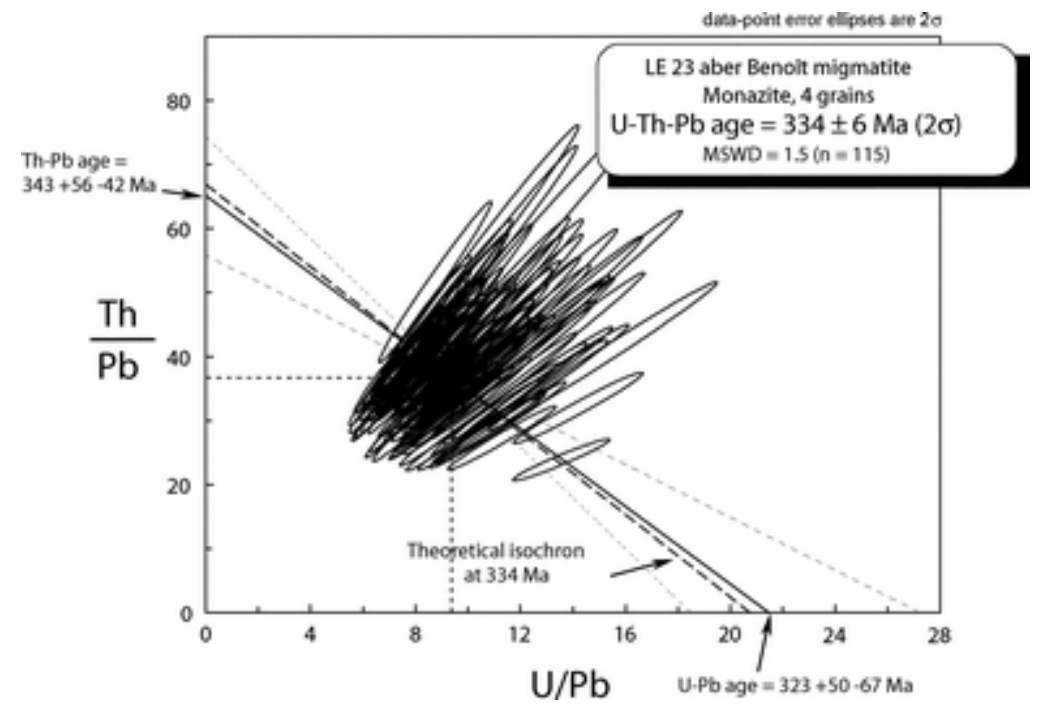

Fig. $12 \mathrm{Th} / \mathrm{Pb}$ versus $\mathrm{U} / \mathrm{Pb}$ isochron diagram for migmatite sample LE 23. The data led to the calculated regression line (thick line), while the theoretical isochron (dashed line) must be included between the two error hyperbolas (thin lines). The condition to allow the mean age to be calculated at the centroid of the population: $334 \pm 6 \mathrm{Ma}$

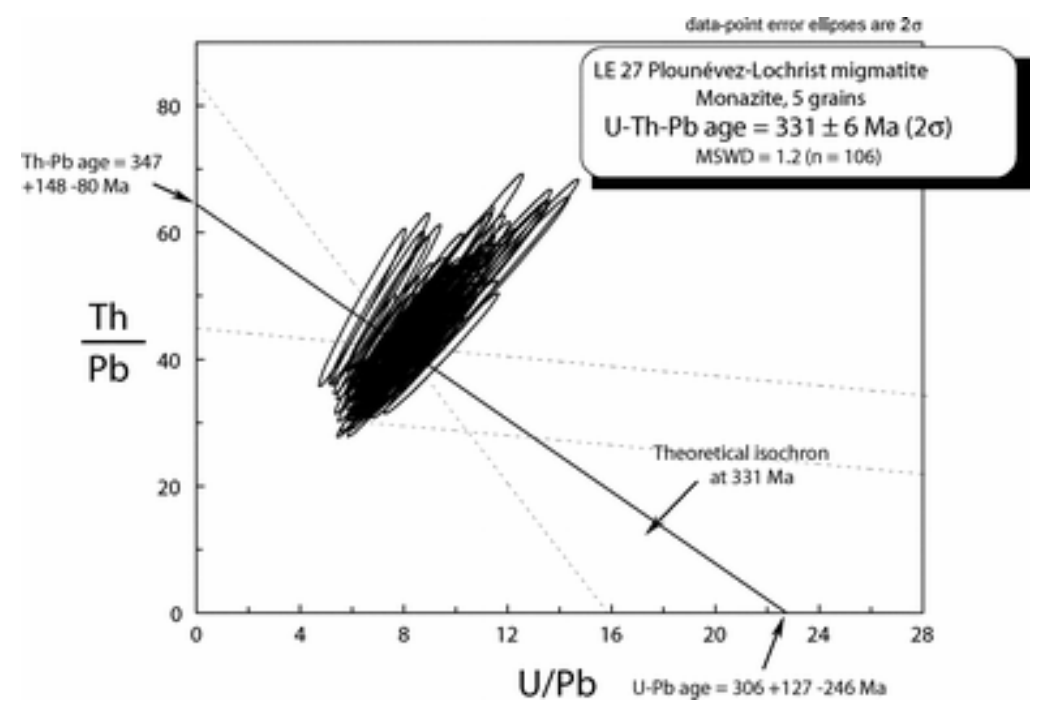

Fig. $13 \mathrm{Th} / \mathrm{Pb}$ versus $\mathrm{U} / \mathrm{Pb}$ isochron diagram for migmatite sample $\mathrm{LE} 27$. The data led to the calculated regression line (thick line), while the theoretical isochron (dashed line) must be included between the two error hyperbolas (thin lines). The condition to allow the mean age to be calculated at the centroid of the population: $331 \pm 6 \mathrm{Ma}$ 


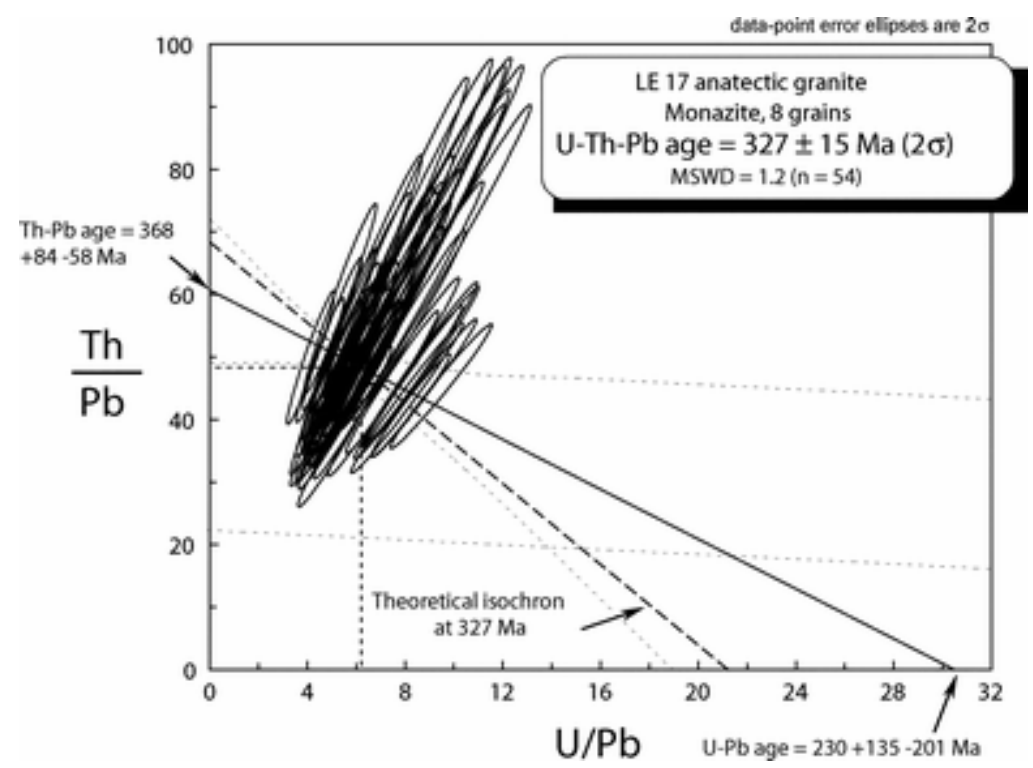

Fig. $14 \mathrm{Th} / \mathrm{Pb}$ versus $\mathrm{U} / \mathrm{Pb}$ isochron diagram for anatectic granite sample LE 17 . The data led to the calculated regression line (thick line), while the theoretical isochron (dashed line) must be included between the two error hyperbolas (thin lines). The condition to allow the mean age to be calculated at the centroid of the population: $327 \pm 5 \mathrm{Ma}$

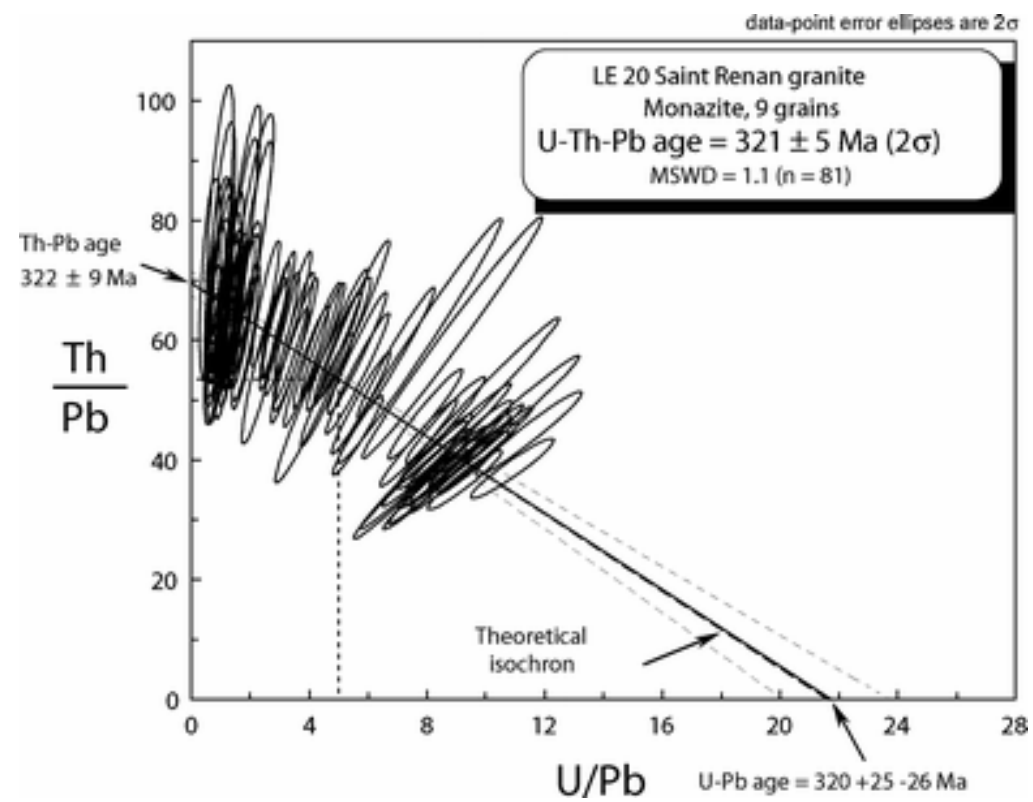

Fig. $15 \mathrm{Th} / \mathrm{Pb}$ versus $\mathrm{U} / \mathrm{Pb}$ isochron diagram for St-Renan granite sample LE 20. Note that despite the wide variation of the composition for these monazite grains, all give the same age within the error as indicated by the slope of the regression line identical to that of the theoretical isochron. The mean age calculated at the centroid of the population is at $321 \pm 5 \mathrm{Ma}$ 


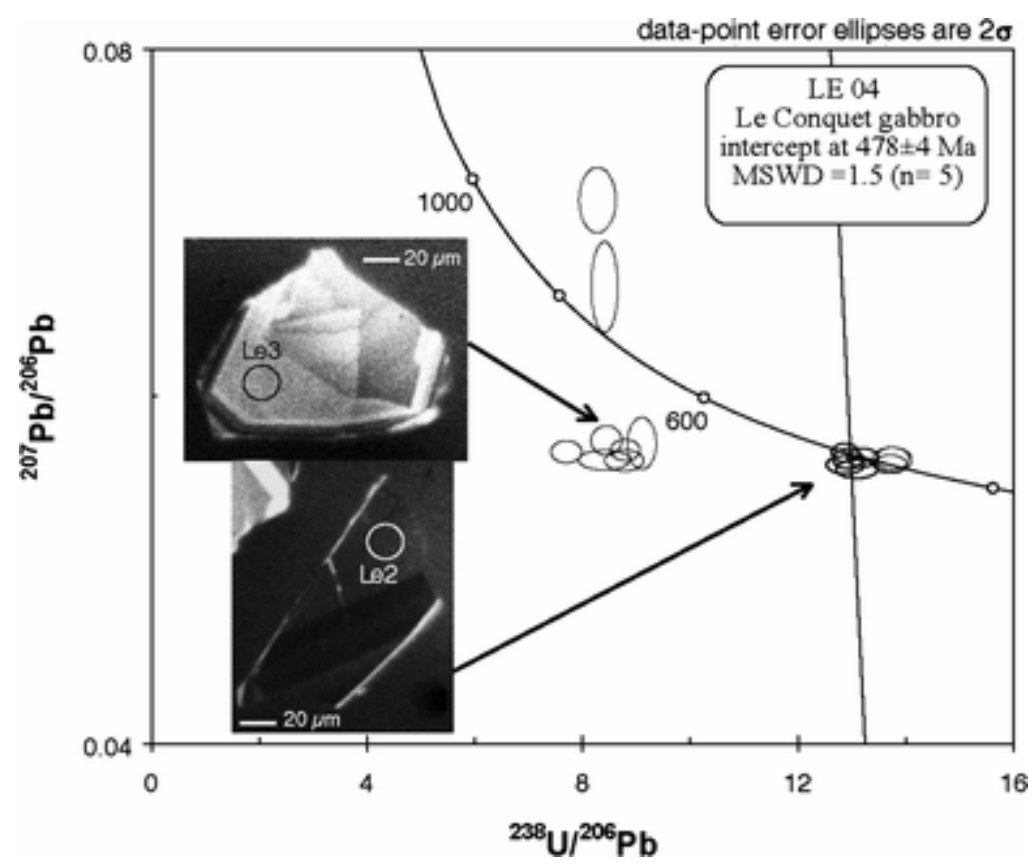

Fig. 16 Common-Pb uncorrected Tera-Wasserburg diagram for data obtained with LA-ICPMS for Le Conquet gabbro (LE 04). Bold ellipses correspond to analyses integrated in age calculation. The gabbro yields a zircon $\mathrm{U} / \mathrm{Pb}$ age of $478 \pm 4 \mathrm{Ma}$

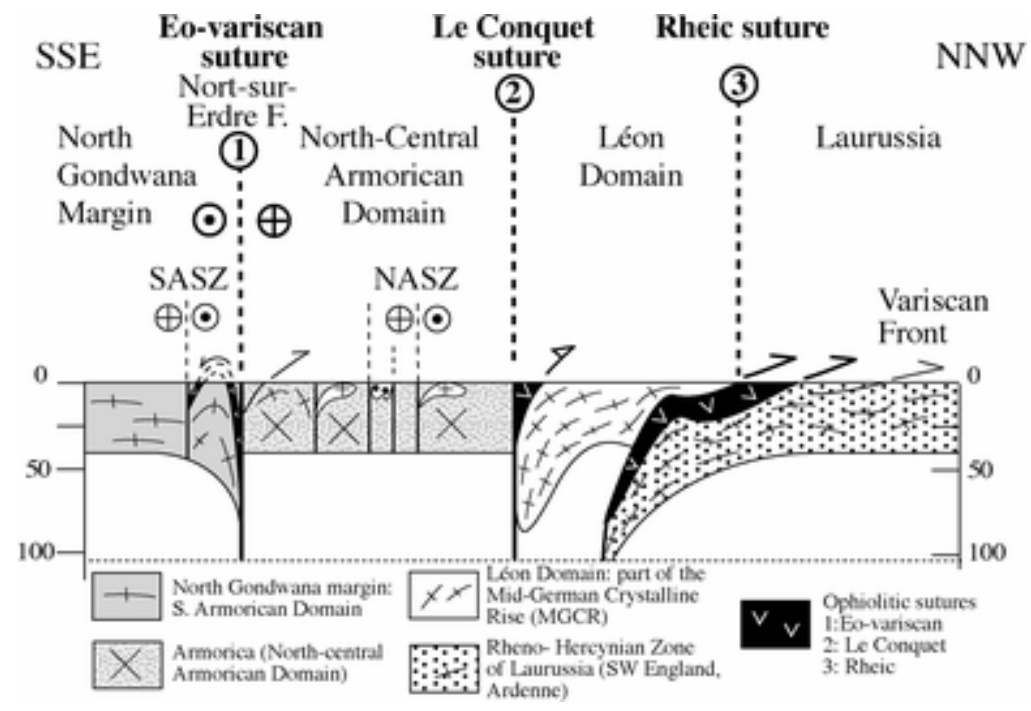

Fig. 17 Crustal scale cross section through the Massif Armoricain and North Britain showing the three suture zones and intervening microcontinents (located in Fig. 1) after the Variscan orogeny at the end of Middle Carboniferous. The Late Carboniferous plutons and the dextral wrench faults have not been represented to emphasize the oldest tectonic events related to microcontinent collision and north-directed thrusting 
Table 
Table 1 LA-MS-ICPMS U-Pb zircon data for Le Conquet gabbro (LE 04)

\begin{tabular}{|c|c|c|c|c|c|c|c|c|c|c|c|c|c|c|}
\hline & $\mathrm{U}(\mathbf{p p m})$ & Th (ppm) & Th/U & Pb* (ppm) & ${ }^{206} \mathrm{~Pb} /{ }^{204} \mathrm{~Pb}$ & f206\% & ${ }^{238} \mathrm{U} /{ }^{206} \mathrm{~Pb}$ & $\pm(\mathbf{1})^{a}$ & ${ }^{207} \mathrm{~Pb} /{ }^{206} \mathrm{~Pb}$ & $\pm(1)^{a}$ & ${ }^{207-206} \mathrm{~Pb}^{*} /{ }^{238} \mathrm{U}$ & $\pm(1)^{a}$ & Age (Ma) & $\pm(\mathbf{1})^{\mathrm{a}}$ \\
\hline \multicolumn{15}{|c|}{ Concordant population analyses } \\
\hline Le4-1 & 515.2 & 369.0 & 0.72 & 34.6 & 14,342 & - & 12.8795 & 0.1420 & 0.05605 & 0.0021 & 0.07764 & 0.00086 & 482.0 & 5.1 \\
\hline Le4-2 & $1,188.3$ & $1,209.6$ & 1.02 & 78.6 & - & - & 13.0926 & 0.1582 & 0.05585 & 0.00022 & 0.07638 & 0.00092 & 474.5 & 5.5 \\
\hline Le4-5 & 489.9 & 378.9 & 0.77 & 32.8 & 13,611 & - & 12.8727 & 0.1019 & 0.05675 & 0.00021 & 0.07768 & 0.00061 & 482.3 & 3.7 \\
\hline Le4-8 & 463.6 & 283.1 & 0.61 & 30.4 & 47,023 & 0.000 & 13.2028 & 0.1161 & 0.05647 & 0.00022 & 0.07574 & 0.00067 & 470.7 & 4.0 \\
\hline Le4-10 & 321.3 & 235.9 & 0.73 & 21.5 & - & - & 12.9262 & 0.1118 & 0.05638 & 0.00024 & 0.07736 & 0.00067 & 480.4 & 4.0 \\
\hline \multicolumn{15}{|c|}{ Discordant population analyses } \\
\hline Le4-3 & 127.7 & 76.0 & 0.60 & 14.4 & 12,364 & - & 7.7017 & 0.1169 & 0.05679 & 0.00026 & 0.12984 & 0.00197 & 787.0 & 11.2 \\
\hline Le4-4 & 38.4 & 20.8 & 0.54 & 4.0 & 578 & 0.954 & 8.2793 & 0.1392 & 0.07129 & 0.00077 & 0.11963 & 0.00201 & 728.4 & 11.6 \\
\hline Le4-6 & 40.2 & 47.0 & 1.17 & 4.1 & 1,077 & 0.369 & 8.4092 & 0.1002 & 0.06628 & 0.00107 & 0.11848 & 0.00141 & 721.8 & 8.1 \\
\hline Le4-7 & 246.4 & 356.5 & 1.45 & 25.4 & 117,837 & - & 8.4038 & 0.1956 & 0.05632 & 0.00023 & 0.11899 & 0.00277 & 724.8 & 15.9 \\
\hline Le4-9 & 105.4 & 65.1 & 0.62 & 10.8 & 10,810 & - & 8.4452 & 0.1171 & 0.05744 & 0.00035 & 0.11841 & 0.00164 & 721.4 & 9.5 \\
\hline Le4-11 & 280.6 & 291.5 & 1.04 & 27.7 & - & - & 8.7735 & 0.1462 & 0.05630 & 0.00025 & 0.11398 & 0.00190 & 695.8 & 11.0 \\
\hline Le4-13 & 44.1 & 41.7 & 0.94 & 4.2 & 3209 & - & 9.1012 & 0.1090 & 0.05728 & 0.00061 & 0.10988 & 0.00132 & 672.0 & 7.6 \\
\hline Le4-16 & 213.2 & 324.2 & 1.52 & 21.0 & 6,568 & - & 8.7924 & 0.1116 & 0.05689 & 0.00025 & 0.11373 & 0.00144 & 694.4 & 8.3 \\
\hline
\end{tabular}

${ }^{\mathrm{a}}$ Uncertainties are given at $\pm 2 \sigma$ level 